\title{
HYDRAULIC FRACTURING STRESS MEASUREMENTS AT FORSMARK AND STIDSVIG, SWEDEN
}

\author{
OVE STEPHANSSON and PER ÅNGMAN
}

\begin{abstract}
STEPHANSSON, OVE and ÅNGMAN, PER, 1986: Hydraulic fracturing stress measurements at Forsmark and Stidsvig, Sweden. Bull. Geol. Soc. Finland 58, Part 1, 307-333.

This paper presents a new development in the use of a multi-hose for hydraulic fracturing, for estimation of in-situ stresses in the Earth's crust. The test procedure and evaluation on hydraulic fracturing in the first and second breakdown method is described. Hydraulic fracturing was performed in Precambrian gneissic rocks at depths down to $500 \mathrm{~m}$ in one borehole at Forsmark, Central Sweden, and down to $150 \mathrm{~m}$ in three boreholes at Stidsvig, Southern Sweden. Tests were conducted in both 76 and $56 \mathrm{~mm}$ boreholes.

The hydraulic fracturing tests at Forsmark are most likely to follow a stress pattern calculated from the second breakdown method, and excluding the influence of pore pressure. The maximum horizontal principal stress at $500 \mathrm{~m}$ depth was found to be about $27 \mathrm{MPa}$. A major discontinuity in the state of stress is found to exist along a large fracture zone at $320 \mathrm{~m}$ depth. The poor rock quality and the large conductivity for the boreholes at Stidsvig speak in favour of stress determination according to the first break down method. Linear regression analysis of the data gives a maximum principal horizontal stress of $14 \mathrm{MPa}$ at $150 \mathrm{~m}$ depth.

Before hydraulic fracturing, overcoring stress measurements were conducted in one borehole at each test site. For the borehole at Forsmark, the magnitudes of the stresses found from overcoring were much larger than those found from hydraulic fracturing. The poor rock quality at Stidsvig excludes the possibility of reliable measurements with the overcoring method.
\end{abstract}

Key words: rock stress, hydraulic fracturing, rock mechanics, downhole measurement, tectonic regimes.

Ove Stephansson and Per Ångman: Division of Rock Mechanics, Luleå University of Technology, Luleå, Sweden.

\section{Introduction}

The magnitude and direction of rock stresses are most important factors in driving mechanisms of plate tectonics, the prediction and control of earthquakes and neotectonics, the extraction of oil, gas and hot-rock geothermal energy. Rock stresses ultimately determine the stability of sur- face and underground structures e.g. dams, mines and underground excavations.

Most of the rock stress measurement methods developed to date require a borehole drilled from the point of access to the depth where stresses are to be determined. With the exception of hydrofracturing and sleeve fracturing, introduced by Stephansson (1983 a), all these 
methods use strain or deformation gauges for sensing changes in borehole dimensions, when existing stresses are relieved.

Stress relief requires overcoring and this operation limits the length of test hole to $500 \mathrm{~m}$ at this stage of development. Other distinct disadvantages of the overcoring methods according to Haimson (1978) are as follows: (1) the requirement of precise determination of rock elastic parameters to calculate stresses from measured strains; (2) the very small area over which stresses are actually determined; and (3) the ineffectiveness in zones of high differential stresses where overcoring could produce discing.

The only feature that hydraulic fracturing has in common with overcoring techniques is that the measurements are conducted in a borehole. It does not require overcoring and it determines stresses directly from the pressure - time recordings. It estimates stresses over larger areas and hence gives a better overall idea of the stress distribution in the rock mass than point measurements. It is unaffected by highly deviatoric stresses. The new technique of measurements in inclined boreholes also eliminates the drawbacks of the assumtion that one of the principal stresses must be vertical. Last but not least, hydraulic fracturing does not require sophisticated downhole instrumentation, Haimson (1978).

During the last few years a number of comparative studies of hydraulic fracturing and overcoring stress measurements have been published. Haimson (1983) describes six case histories, with good to excellent agreement as far as both stress magnitudes and directions are concerned. Of particular interest is the case at two tunnel complexes of the Nevada Test Site. The state of stress at the Stripa Mine for radioactive waste isolation studies has been measured both in a $381 \mathrm{~m}$ deep borehole drilled from the surface, and in holes drilled from the drifts underground, Doe et al. (1983 a, b). Hydraulic fracturing and several overcoring methods have been used (Luleå triaxial gauge, CSIRO gauge, USBM gauge, Swedish State Power Board). The results obtained from overcoring and hydraulic fracturing agree well, particularly for the magnitude and orientation of the greatest stress. Flat jack relief, overcoring and hydraulic fracturing was tested at the Fanay-Augères Mine in France by Bertrand and Durand (1983). Analogously to the programme of overcoring and hydraulic fracturing conducted at Camborn of South England, reported by Pine et al. (1983), stress data are required for the geothermal energy research programmes. At Camborne the stress magnitudes determined by the overcoring test with USBM and CSIRO gauges were close to those measured by the hydrofracture tests at the same depth.

In this paper we describe hydrofracture stress measurements from two boreholes in the Precambrian bedrock of Sweden. One test was conducted down to a depth of almost $500 \mathrm{~m}$ in granitic gneisses at the Forsmark nuclear power plant, Central Sweden. The other tests were conducted at shallow depths in granitic gneisses at Stidsvig, Southern Sweden. At Stidsvig boreholes with both 76 and $56 \mathrm{~mm}$ diameter were used for hydraulic fracturing. At both sites, and for the same boreholes, rock stress measurements were conducted by the overcoring technique used by Swedish State Power Board. This enables us to compare results from hydrofracturing and overcoring stress measurements. We can then demonstrate the ability of our hydrofracturing technique to obtain a reliable estimate of the insitu stress state in two different tectonic regimes of the Fennoscandian Shield.

\section{Test equipment for hydraulic fracturing}

Test equipment for hydraulic fracturing has, in the past few years, undergone considerable technical development. However, all hydraulic fracturing systems consist of certain basic units which are required for stress measurements. These are as follows:

1) Inflatable straddle packers to seal off the test section. 
2) Pump to inflate packers and pressurize test zone.

3) Pressure and flow recording system.

4) Fracture detection system.

The first traditional, and still most commonly used method for lowering the packer assembly into the borehole, involves the use of a drill string. This technique was used principally because the oil companies had both equipment, and considerable experience in handling drill rods from oil exploration. The tubing has the advantage that one can reach great depths (several thousand meters). However, at present, the economics of sending a tool down into the borehole on the end of a tubing string are unfavourable, since this necessitates a drilling rig, large handling costs and a timeconsuming operation. It also has the disadvantage of providing only one hydraulic line for both packer inflation and test zone pressurization. This implies that the packers must be set first, at a certain high pressure, greater than the expected breakdown pressure, after which the test zone can be fractured. This is undesirable, since there always is a risk that the borehole will be fractured prematurely with the pressurized packers. The test section pressure recordings will then be incorrect. The hydraulic pressure is usually diverted to packers or the test zone by some kind of push and pull valve. Some of these are already available for drill stem testing in oil wells.

Several other test equipment systems have been suggested and developed, e.g. a hydraulic fracturing tool on the end of a wireline, where the packer assembly and pumps would be built into one tool and lowered into the borehole. The system has the advantage of making the drill string obsolete, and the wireline tool could then be run up or down at relatively high speeds. The pump would obtain its power supply from either stored gas pressure in the tool, or through electric cables in the wire-line. Since the quality of the fluid in the boreholes varies considerably and is difficult to filter, the hydraulic fluid must be stored in the tool.
At the Ruhr University at Bochum, the packer assembly is lowered into the borehole with a steel cable enclosing an electric signal cable simultaneously with a high pressure hydraulic hose to pressurize the packers and fracture the test zone, Rummel et al. (1983). The system includes a push- and pull valve at the top of the upper stradle packer to direct hydraulic pressure to either the packers or the test section. Another, similar system is the one under development by Enever and Wooltorton (1983). This consists of a flexible »endless tubing unit» on a large drum.

Several fracture detection systems have been studied. However, the most reliable and widely used system is the impression packer, which, after fracturing is inflated on the fractured test zone, to obtain an impression of the borehole wall. On the packer, fractures will appear as small ridges where the soft rubber was forced into the fracture. Fracture orientation is usually determined by a compass mounted adjacent to the impression packer.

\section{The hydraulic fracturing stress measurement system at the Lulea University of Technology}

The Luleå hydraulic fracture stress measurement system is shown in Fig. 1. It consists of the usual double packer assembly for sealing off the test zone. An impression packer and TV-camera are used for fracture detection. Fracture orientation is determined with a compass in the TVcamera, which is mounted below the impression packer. The system has complete down hole equipment for two different hole sizes, ø $56 \mathrm{~mm}$ and $\varnothing 76 \mathrm{~mm}$, both of which are Swedish standards.

The down hole equipment is lowered into the borehole and pressurized through a 500 meter long multi-hose. A section view of the multihose is shown in Fig. 1. The multi-hose contains three hydraulic hoses ( $\varnothing 10 \mathrm{~mm}, 2 \times \varnothing 8 \mathrm{~mm}$ ). One is used for inflating the packers, one for pressurizing the test zone and one is currently not in use. The redudant hydraulic hose might, in 


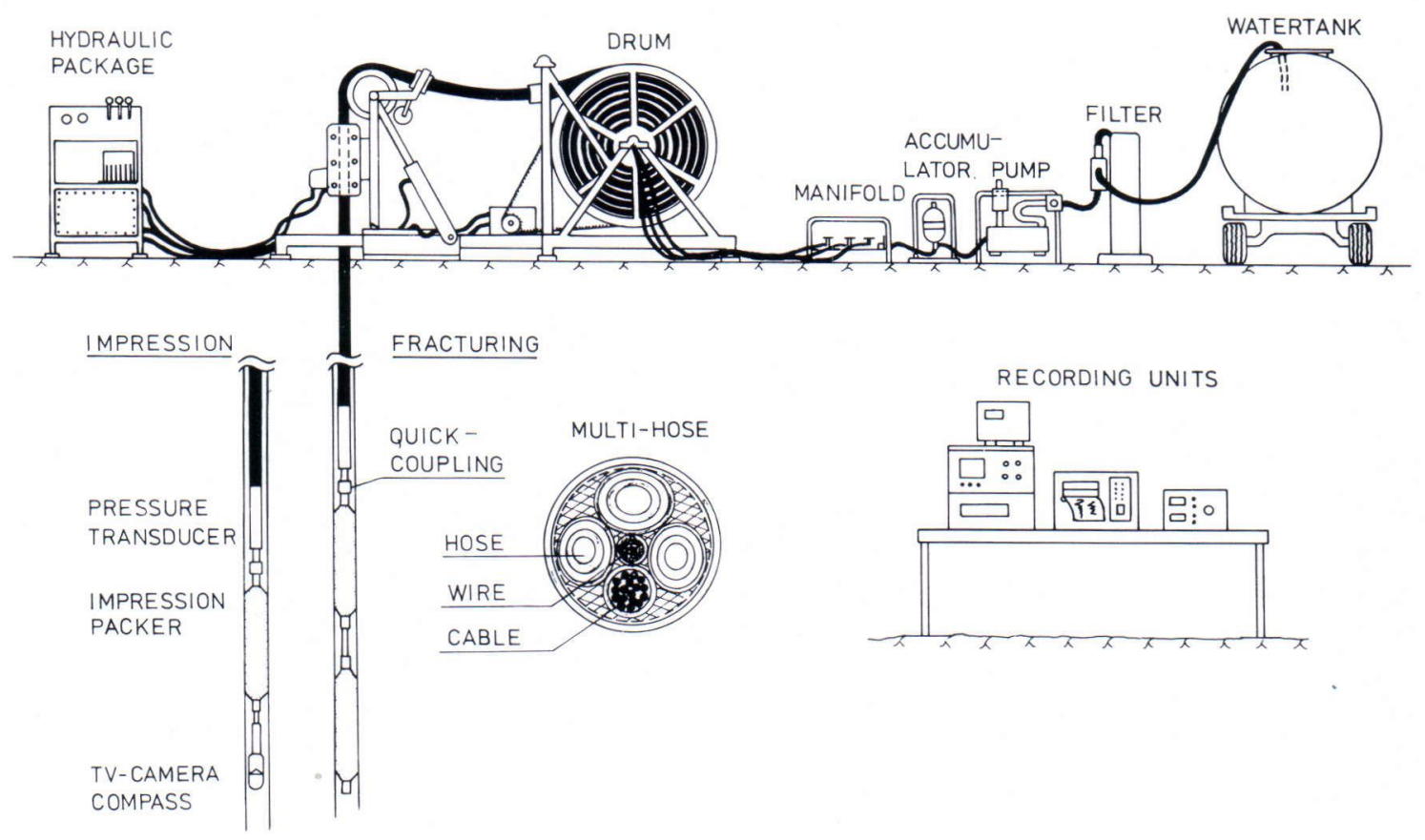

Fig. 1. The hydraulic fracturing stress measurement system at the Luleå University of Technology.

future, be used to operate downhole mechanical equipment e.g. hydraulic valves. The multi-hose also has a 16-wire signal cable used for the TVcamera and pressure transducers. The cord in the hydraulic hoses is made out of synthetic fibers which makes them light weight and flexible. They float in the borehole. The outer diameter of the multi-hose is $46 \mathrm{~mm}$ and it weighs approximately $1 \mathrm{~kg}$ per meter, when it is submerged in water. Thus, the lifting capacity of the steel cable ( 3.3 ton) is used mainly if one gets stuck in the borehole.

A specially constructed connection for the multi-hose was developed which makes rapid connection or disconnection of different tools possible regardless of whether they make use of hydraulic hoses or electrical cables. This also makes it possible to attach and operate almost any kind of geophysical logging tool. The existing stress measuring system can easily be modified for the sleeve fracturing method when it is fully developed, Stephansson (1983 a).
Feeder and drum. The feeder and drum are similar to those used in irrigation systems. It is operated by hydraulic motors, powered by a $7.5 \mathrm{~kW}$ 3-phase electric motor/pump. The multihose can be moved at variable speeds (up to approximately $1 \mathrm{~meter} / \mathrm{sec}$ ), and the feeder can be deviated for operation in inclined boreholes.

Pump and pressure/flow regulating system. The hydraulic pressure for packer inflation and hydrofracturing was provided by an air-powered single cylinder HASKEL pump with a capacity of 9.6 liters/minute at a maximum pressure of $40 \mathrm{MPa}$. The pump is equipped with an air diaphragm valve which permits the pressure supply to be set at desired levels. The manifold with flow and pressure regulating valves was built with stainless steel parts, as far as possible, to avoid corrosion. An important feature of the system is that it is possible to regulate, independently, the pressure in both packers and the test section simultaneously. This was made possible by installing a differential pressure valve, 
which could be set at a desired value. The differential pressure between packer and test section could then be kept constant (automatically) during the entire pressurization cycle.

Recording system. The test section fluid pressure was measured by a small downhole electric pressure gauge and plotted on a four channel chart recorder along with the packer pressure and flow rates. The turbine flow meter was mounted in the manifold. Both the packer and the test section pressure were also measured at the surface and recorded on a digital display.

\section{Test procedure and evaluation of hydraulic fracturing data}

The standard test procedure for hydraulic fracturing stress measurements is performed in three steps:

1) TV-logging of borehole and inspection of drill core to locate suitable test sections.

2) Lowering the double-packer assembly into the borehole to the test section, sealing of test section by inflating packers, and fracturing the test zone by fluid injection. Test zone pressure, packer pressure and fluid flow rates are plotted continuously on a chart recorder.

3) Impression packer lowered into the borehole and inflated at the fractured test zone. Packer and fracture orientation is determined by means of a compass mounted in the TVcamera.
A typical recording from the Stidsvig test site is shown in Fig. 2.

The packers are set and inflated. The test zone is pressurized until a fracture is initiated at $\mathrm{P}_{\mathrm{c} 1}$. The pumping is then immediately stopped, $\mathrm{Q}=0$, to permit the pressure to fail to the »shutin» pressure $\mathrm{P}_{\text {sh }}$. The »shut-in» pressure stabilizes (in general) as soon as the hydraulic fracture has closed, not permitting any further leakage into the formation.

The same pump cycle is repeated at various flow rates. Once a breakdown pressure $\mathrm{P}_{\mathrm{cl}}$, a re-frac pressure $P_{c 2}$, and a shut-in-pressure $p_{s h}$, has been established the three principal stresses can be calculated. We use the classical formula, originally presented by Hubbert and Willis (1957):

$$
\sigma_{\mathrm{H}}=3 \sigma_{\mathrm{h}}-\mathrm{P}_{\mathrm{cl}}+\mathrm{T}-\mathrm{p}
$$

where $\sigma_{\mathrm{H}}=$ maximum horizontal principal stress

$\sigma_{\mathrm{h}}=$ minimum horizontal principal stress equal to the shut-in pressure $\mathrm{P}_{\text {sh }}$

$\mathrm{P}_{\mathrm{c} 1}=$ first breakdown pressure

$\mathrm{T}=$ hydrofracture tensile strength

$\mathrm{p}=$ pore pressure

The above method for determination of the maximum horizontal principal stress is called the »first breakdown method», Doe et al. (1983 b). The application of this method requires a known rock tensile strength, $\mathrm{T}$, and pore pressure, $\mathrm{p}$. Here, we have a controversy, since some research

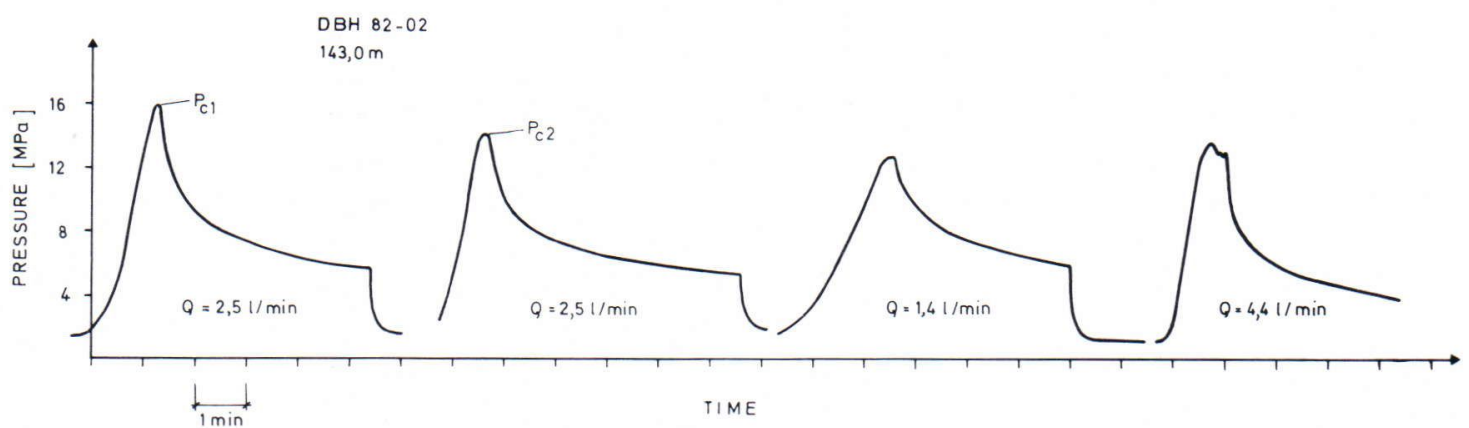

Fig. 2. Recording from borehøle $\mathrm{DBH} 82-02$, at 143.0 meters depth, at Stidsvig. 
groups, like Rummel et al. (1983), state that in a crystalline rock (eclogite, granite) the pore pressure in the rock at depth can be neglected. Others, like Doe et al. (op. cit.), applied a pre-pressure for evaluation of the stress state for the surface borehole at the Stripa Mine. However, they regarded the test around the full scale heater test to be drained. Thus no pore pressure term was used.

The second alternative method for analysis of hydrofracture data suggests that the tensile strength should be the difference between the first and subsequent breakdown pressures, $\mathrm{T}=$ $\mathrm{P}_{\mathrm{c} 1}-\mathrm{P}_{\mathrm{c} 2}$. Equation (1) now becomes

$$
\sigma_{\mathrm{H}}=3 \sigma_{\mathrm{h}}-\mathrm{P}_{\mathrm{c} 2}-\mathrm{p}
$$

Where $P_{c 2}$ is the re-fracturing pressure. This method has been called the »second breakdown method» by Doe et al. (1983 b). Notice that equation (2) is applicable only for $\sigma_{\mathrm{H}} \leq 2 \sigma_{\mathrm{h}}$ i.e. the second breakdown pressure must be larger than the shut-in pressure.

The two methods for analysis of hydrofracture data were applied in this study. However, more assumptions must be made to evaluate the stress state.

1) One principal stress is assumed to be vertical i.e. parallel to the borehole and equal to the overburden pressure; $\sigma_{\mathrm{v}}=\mathrm{p} \cdot \mathrm{g} \cdot \mathrm{h}$. Overwhelming field evidence shows that one principal stress is nearly vertical in most Precambrian geological formations in Scandinavia and North America.

2) The rock is considered to be homogeneous, linearly elastic and impermeable, a reasonable assumption for the crystalline rocks found at Forsmark and Stidsvig.

3) The hydraulic fracture initiates and propagatets in a plane perpendicular to the least horizontal principal stress $\left(\sigma_{\mathrm{h}}\right)$ which is equal to the shut-in pressure $\mathrm{P}_{\mathrm{sh}}$. This assumption is strongly supported by both laboratory data and theoretical studies (Hubbert and Willis (1957), Haimson and Fairhurst (1970), Haimson and Avasthi (1974)).
If $\sigma_{v}$ is the least principal compressive stress, a vertical fracture will nevertheless initiate at the borehole wall, yielding the first shut-in pressure $\left(\mathrm{P}_{\text {sh1 } 1}\right)$. The fracture often propagates into a horizontal plane and opens it up. A second shut-in pressure $\left(\mathrm{P}_{\mathrm{sh} 2}\right)$ will then be recorded. We have

$$
\begin{aligned}
& \mathrm{P}_{\text {sh1 }}=\sigma_{\mathrm{h}} \\
& \mathrm{P}_{\mathrm{sh} 2}=\sigma_{\mathrm{v}}
\end{aligned}
$$

In most cases it is possible to determine a principal stress orientation by detecting fracture orientation. Here, an impression packer can be used and, one assumes the fracture to be oriented perpendicular to the least principal stress. However, it is not always possible to follow and interpret in such a straight forward manner the relatively simple standard procedures outlined above.

It has been noted by Smith et al. (1981), and suggested by Kehle (1964) that fractures could be prematurely initiated by the pressurized packers and not nessesarely from the hydraulic fluid in the test section. Warren (1981) has made theoretical studies of packer induced stresses on the borehole wall. Warren found significant stress concentrations around the packer ends, which may be sufficient to initiate fractures, before any hydraulic pressure is applied.

Independently of the theoretical analysis by Warren (1981), packer induced stresses have been tested by Stephansson (1983 b). Strain gauges were mounted on the outside of a steel tube and both single- and double-packer assemblies were pressurized inside the steel tube. Although Stephansson's and Warren's results cannot be compared directly, since Stephansson had the strain gauges on the outside of the steel tube, Stephansson's results indicate that stress concentrations around the packer ends are not as large as suggested by Warren. However, like Warren, Stephansson found that the differential pressure, between packers and test section, playes a very significant role and should be kept as small as possible. This implies that the test zone and 
the packers should be pressurized simultaneously. Special precautions were taken in the development of our hydraulic fracturing stress measuring system to meet this condition. Practical tests suggest that the differential pressure should be set at approximately $2-4 \mathrm{MPa}$, which is sufficient to enable the packers to seal effectively.

No standardized method exists for the determination of the instantaneous shut-in pressure. In practice, this determination can be a highly subjective process. Several techniques have been suggested. The problem has been extensively studied by Gronseth and Kry (1983), Hickman et al. (1981) and McLennan and Roegiers (1983).

Figure 2 illustrates an all too common problem. Here we have a complicated transient behaviour in the pressure response. This makes it difficult to estimate directly, the instantaneous shut-in pressure (ISIP). The smooth pressure drop slowly dropping off to zero, makes it extremely difficult to readily correlate any characteristic feature on the curve to the shut-in pressure. If pumping is very slow, and if simultaneous timebase recording of both the pressure and flow rate is conducted, a simple relationship formulated by Perkins and Kern, and quoted by Haimson (1978) can be used to obtain the shut-in pressure $\left(\mathrm{P}_{\mathrm{sh}}\right)$ values

$$
\left(\mathrm{P}_{1}-\mathrm{P}_{\mathrm{sh}}\right) /\left(\mathrm{P}_{2}-\mathrm{P}_{\mathrm{sh}}\right)=\left(\mathrm{Q}_{1} / \mathrm{Q}_{2}\right)^{1 / 2}
$$

where $\mathrm{P}_{1}$ and $\mathrm{P}_{2}$ are two pressure levels corresponding respectively, to the two flow rates $Q_{1}$ and $\mathrm{Q}_{2}$.

For many years, reservoir engineers in the petroleum industry have used special data manipulation techniques to study fluid flow behaviour pattern in oil wells, e.g. log-log and semilog plots of pressure and time. Similar analysis of hydrofracturing data have been suggested by Sun and Mogan (1974), and also been discussed by Aamodt and Kuriyagawa (1983) and Doe et al. (1983 a). Good summaries of reservoir engineering considerations have been provided by Cinco-Ley et al. (1981) and Cinco-Ley (1982).

These methods, applied to hydrofracturing pressure data from Stidsvig, have yielded various results. Severe difficulties were frequently encountered in the identification of characteristic features on the curves.

However, reasonable results were obtained from Stidsvig and Forsmark, by using the relatively simple method shown in Fig. 3 a. Here, two tangent lines are drawn and the intersection of the two lines defines the instantaneous shutin pressure (ISIP).

Furthermore, a very similar method for shutin pressure determination, described by Aamodt and Kuriyagawa (1983) has been used. The timepressure curve is plotted in a semi-logarithmic diagram, shown in Fig. 3 b, in which a tangent line is drawn. The shut-in pressure is obtained where the tangent line intersects the pressure axis fixed in time to where the pumping was stopped. The two methods have yielded very similar results.

One of the boreholes tested in Stidsvig, DBH 82-03, was inclined at approximately $30^{\circ}$ to the vertical. In vertical boreholes one principal stress $\left(\sigma_{\mathrm{v}}\right)$ is assumed to be parallel to the borehole
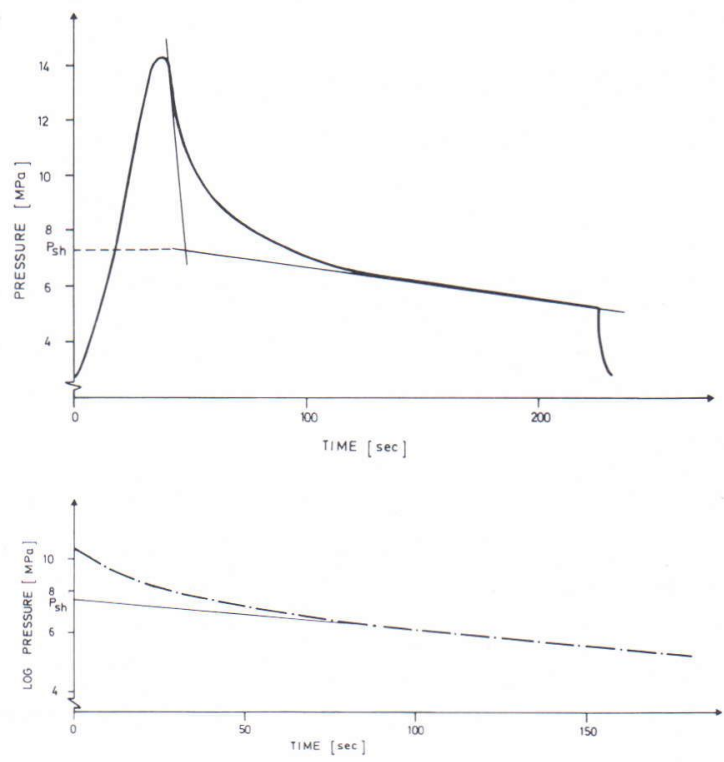

Fig. 3. Time pressure chart from borehole DBH 82-02, at 143.0 meters, Stidsvig. A) Simple method of shut-in pressure determination. B) Semilogarithmic plot of the time-pressure curve in figure 2 . 
axis. In the case of inclined holes this is obviously not the case. Here the inclination of the borehole, both to the vertical and to the principal stress directions must be considered. An analytical study of hydraulic fractures in arbitrarily oriented boreholes has been made by Richardsson (1983). The effect of borehole inclination is thoroughly discussed by Pine et al. (1983). These studies, and the experimental results obtained by Danesley (1973) indicate that shut-in pressures correlate relatively well to $\mathrm{P}_{\mathrm{sh}}$, taken in vertical holes. However, fracture impressions taken in inclined boreholes has (both in theoretical studies and practical experiments) proved to be misleading if these are used to determine the overall stress orientation.

In hydraulic fracturing stress measurement, the tensile strength of the rock mass can be defined as the difference between the breakdown pressure, $\mathrm{P}_{\mathrm{c} 1}$, and the re-fracturing pressure, $\mathrm{P}_{\mathrm{c} 2}$, cf. equation (2). However, the tensile strength of the rock is subjected to a confining pressure, and an internal water or oil pressure is applied to a central hole, the core will fracture once the pressure exceeds the confining pressure and the tensile strength of the rock. Rewriting the breakdown pressure, $P_{c}$, in equation (1) for a confining pressure, $\mathrm{P}_{\mathrm{o}}$, we obtain

$$
\mathrm{P}_{\mathrm{c}}=\mathrm{T}_{\mathrm{o}}+2 \mathrm{P}_{\mathrm{o}}
$$

where $T_{0}$ is the tensile strength. This is a very realistic laboratory test to determine $\mathrm{T}$ since it resembles hydrofracturing in the field. The arrangements for the test are shown in Fig. 4. Results for the rock types at Forsmark and Stidsvig, for realistic confining pressures are shown in Fig. 5. We notice that all the data points are situated below the theoretical line. This is explained in detail by Stephansson (1983 b).

It was not clear how to extrapolate the smallcore data to the expected tensile strength of rock from the $76 \mathrm{~mm}$ or $56 \mathrm{~mm}$ holes most commonly used in field tests. Doe et al. (1983 b) applied a deterministic fracture mechanics approach. They calculated a $54 \%$ reduction in tensile strength

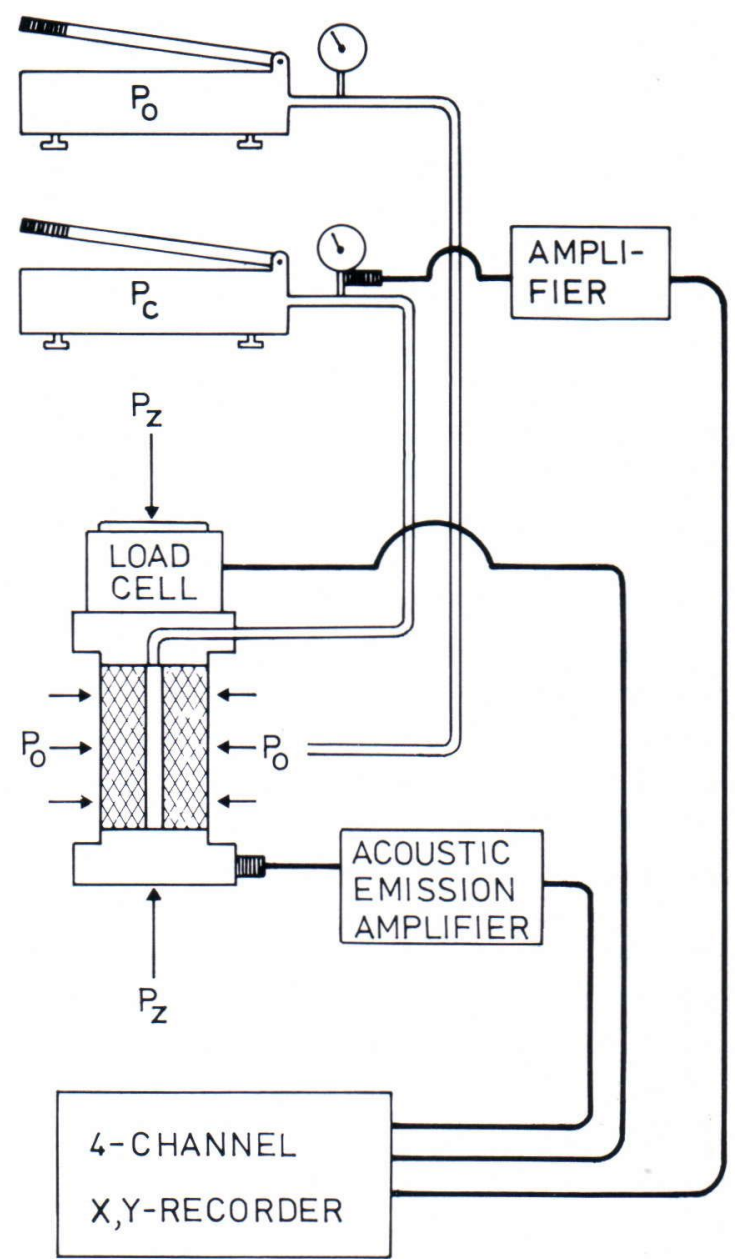

Fig. 4. Testing of tensile strength of rock by hydraulic fracturing of confined drill core. $\mathrm{P}_{\mathrm{o}}=$ confining pressure, $\mathrm{P}_{\mathrm{c}}=$ fracturing pressure.

of a 3 -inch hole relative to a 1/4-inch hole. For this study we use a $50 \%$ reduction from the laboratory tests on the $76 \mathrm{~mm}$ boreholes, i.e. 8.8 MPa for the gneiss at Forsmark and 8.5 MPa and $12.5 \mathrm{MPa}$ for the gneiss and amphibolit respectively at Stidsvig.

\section{Overcoring stress measurements according to the Swedish State Power Board technique}

The Swedish State Power Board stress measurement technique was adapted from the well known 

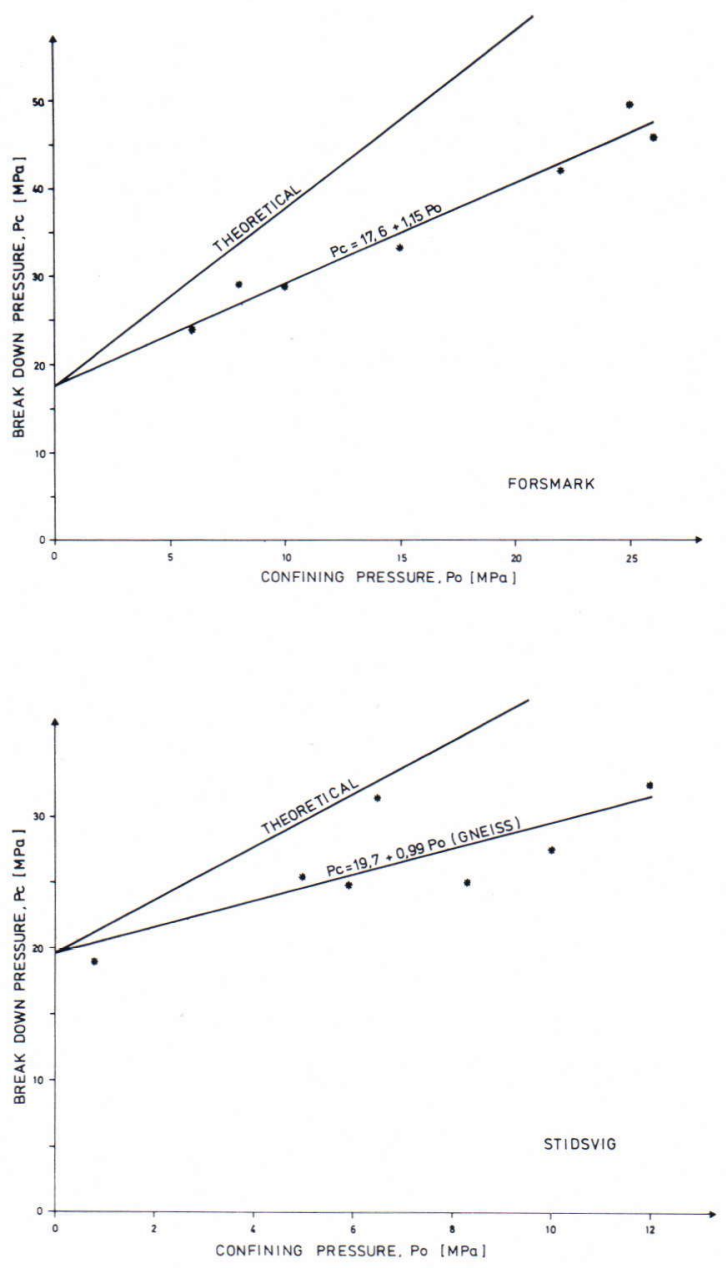

Fig. 5. Break down pressure versus confining pressure for hydraulic fracturing of core samples. A) Forsmark gneiss. B) Stidsvig gneiss and amphibolite.

overcoring principal of Leeman and Hayes (1966). The unique feature of this technique is that measurements can be conducted in waterfilled boreholes down to a depth of 500 meters. The method has been thoroughly described by Hiltscher et al. (1979).

In this method three strain gauge rosettes are cemented to the wall of a small borehole at the bottom of a larger borehole. Readings of the strain gauges are taken before and after stress relief by overcoring. The triaxial stress tensor can then be calculated from the strains recorded.
Young's modulus and Poisson's ratio are determined in the laboratory.

The measurement procedure is shown schematically in Fig. 6. A ø $76 \mathrm{~mm}$ borehole is drilled to the desired depth. A smaller core, ø $36 \mathrm{~mm}$, is then drilled at a further distance of $400 \mathrm{~mm}$. The smaller core is inspected to determine whether the test section is suitable or not.

The strain rosettes are glued onto the borehole wall by a tube shaped probe after the borehole has been thoroughly washed. The probe is lowered into the borehole with a combined carrying - and measuring cable. It consists essentially of three plastic tounges, interconnected in their upper parts, and with the strain gauge rosettes held on their lower ends.

The rosettes are submerged in a glue pot during the descent. The probe mechanism is triggered by two pins touching the bottom of the large borehole when the correct position for cementing is reached. The probe is hoisted after the cement has cured (two hours), and the probe and strain gauge rosette orientation have been determined by means of a compass.

A hollow core with the strain gauges is obtained by overcoring. The wires are connected and readings are taken from the strain gauges as soon as the core has been hoisted. The measurements are continued for about two hours. The temperature of the core is held fixed (at the borehole temperature) while measurements are taken to observe any creep and also the influence of any intruding water.

The core, strain gauge rosettes and cementing are also subsequently tested in the laboratory by controlled uniaxial loadings and additional strain gauges to determine if the recorded borehole measurements are acceptable.

\section{Stress measurements at Forsmark}

This study was made at the Forsmark Nuclear Power Plant about $130 \mathrm{~km}$ north of Stockholm 


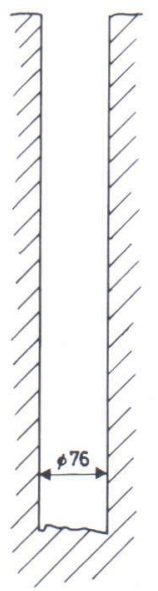

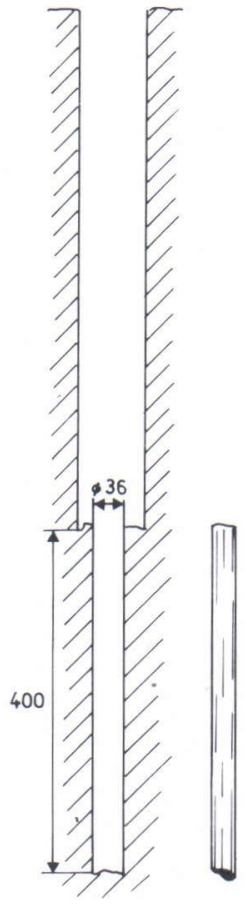

2

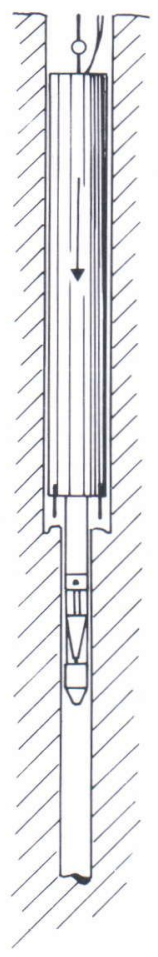

4

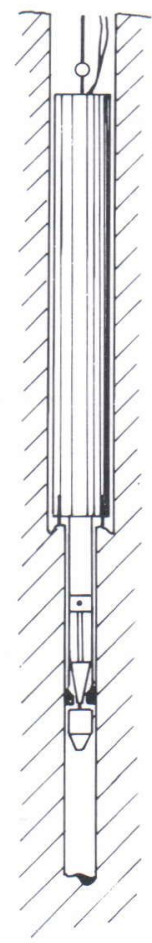

5

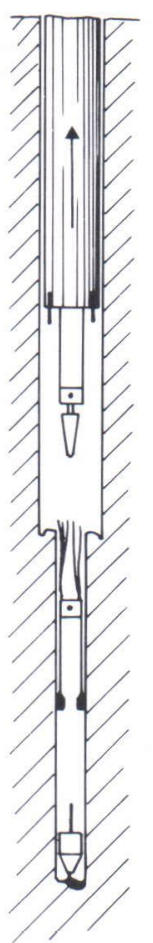

6

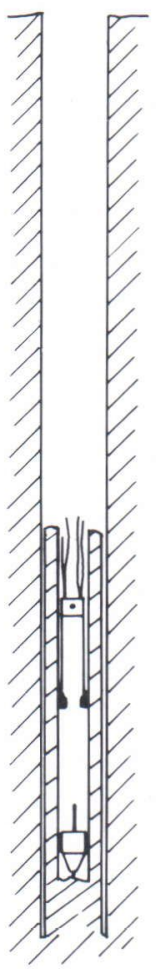

7

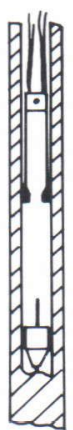

8

Fig. 6. Procedures for overcoring stress measurements adopted by the Swedish State Power Board technique. 1) 78 mm borehole, 2) $36 \mathrm{~mm}$ borehole, 3) appraisal of small core, 4) position of the probe before triggering off mechanism, 5) cementing first measurement, 6) release of the carrier and hoisting of the probe, 7) overcoring, 8) second measurement. After Hiltscher et al. (1979).

(see Fig. 7). Here the Swedish State Power Board has been developing and testing its new overcoring technique for rock stress measurements. This is described by Hiltscher et al. (1979) and Martna et al. (1983).

\section{Outline of geology and tectonics}

The Precambrian bedrock at Forsmark consists principally of foliated granitic gneisses, with inlets of mica schists and diorite dolerites, amphibolites and pegmatites that form dykes and small massifs. A medium to fine grained granitic gneiss forms the major rock type of borehole DBT-1, where hydraulic fracturing was made after the overcoring was completed. The tectonics of the area have been described by Stephansson
(1975). They are the result of polydiapirism during the intrusion of the granitic rocks at the Svecokarelian orogeny, 1800-1600 mys ago. Postorogenic tectonic events formed major shear zones. These run in an approximately NW-SW direction, with an average frequency of $5 \mathrm{~km}$. Sub-vertical fracture sets running NW-SE and NE-SW, and a set of horizontal fractures dominates the cataclastic tectonics of the area. Siltfilled joint in horizontal open joints in the uppermost part of the bedrock is a characteristic feature in the Forsmark area (Stephansson and Eriksson (1975) and Carlsson (1979)).

The granitic gneiss at DBT-1 has a granodioritic composition, and the foliation dips $70^{\circ}-90^{\circ}$ to the NE. Fractures with weathered or coated surfaces are common, with an average frequency 


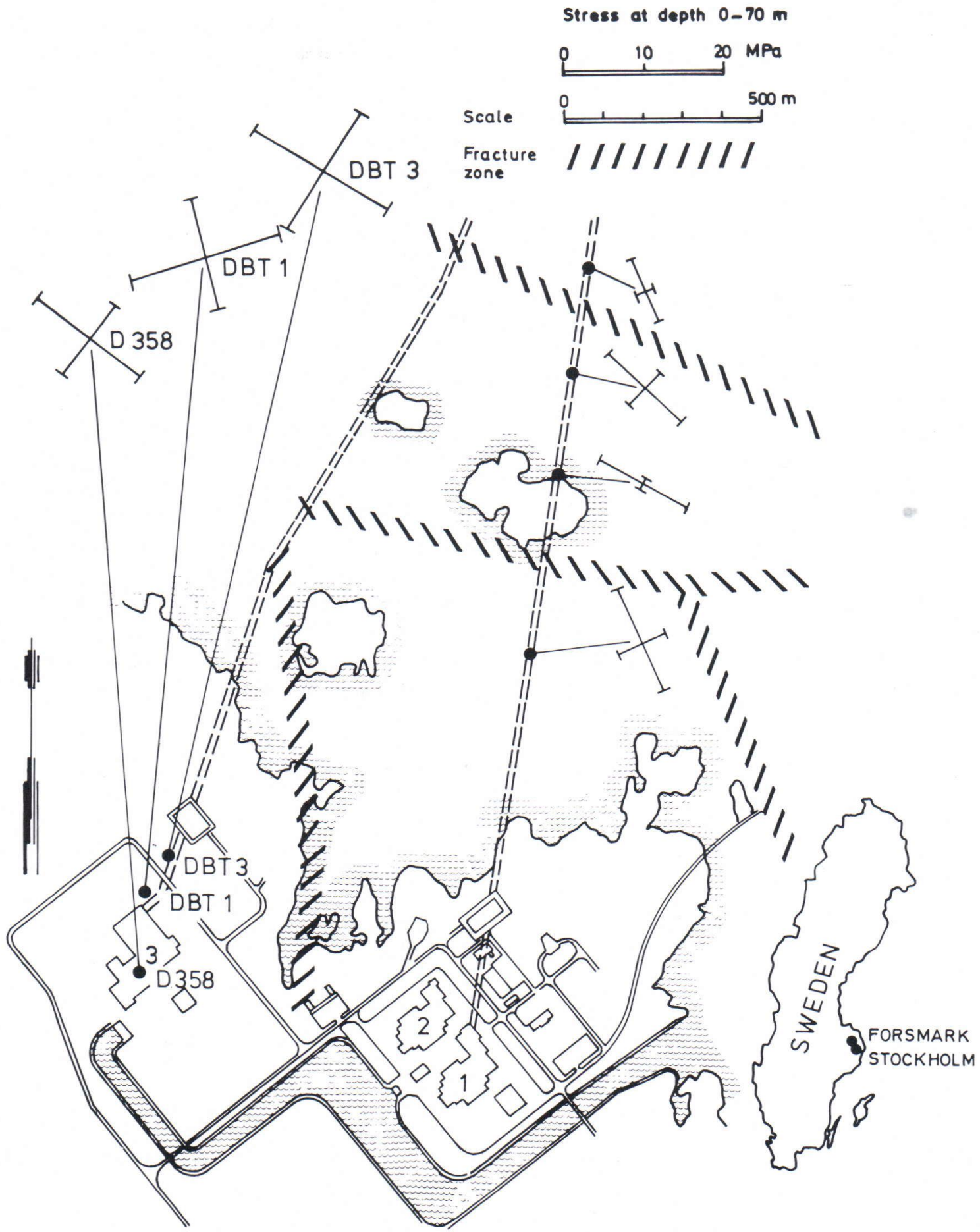

Fig. 7. Location of Forsmark Nuclear Power Plant in Sweden. Recorded rock stresses by overcoring technique in the outlet tunnel and in boreholes from the surface. Hydraulic fracturing was conducted in borehole DBT 1 and the northern corner of reactor number 3. Modified after Martna et al. (1983). 
of 1.9 fractures per meter, down to a depth of $250 \mathrm{~m}$. At $320 \mathrm{~m}$ depth, the core penetrates a fracture zone (whose thickness exceeds $3 \mathrm{~m}$ ) of red granitic gneiss with a $40 \mathrm{~m}$ core of crushed rocks. The dip of the fracture zone has not been determined neither from other boreholes nor by geophysical methods. However, a low dip is anticipated.

\section{Results of hydraulic fracturing stress measurements}

A total of 17 suitable sections for hydraulic fracturing were selected by inspection of the core and by TV-logging of the borehole. From these results, 9 hydrofracturing tests were conducted at different levels of the borehole. Typical pressure time recordings from a selected number of fracturing tests are shown in Fig. 8. In general, the breakdown occurs at pressures between 5 and $25 \mathrm{MPa}$, with a clear trend of increasing breakdown pressure with depth. The re-fracturing pressure, $\mathrm{P}_{\mathrm{c} 2}$, varies between 4 and almost $25 \mathrm{MPa}$, which gives a corresponding field tensile strength between 2 and $14 \mathrm{MPa}$. The very low tensile strength obtained for some of the test sections indicates the existance of latent joints. However, they could not be detected from either core inspection or TV-inspection. The shut-in pressure was determined from the principal of semilogarithmic plotting. The results thus obtained show a major increase in magnitude below the fracture zone in the borehole, Table 1.

The stress state for DBT-1 was evaluated from the following two techniques:

- second breakdown method, equation (2)

- first breakdown method, equation (1)

For the minimum horizontal principal stress, $\sigma_{\mathrm{h}}$, the only difference is the addition of the pore pressure, $p$, to the shut-in pressure for the evaluation according to the first breakdown method. Both methods show an almost uniform increase in the minimum stress, $\sigma_{\mathrm{h}}$, with depth with a tendency for a discontinuity in the stress state below the fracture zone, $c f$. Fig. 9. In the calculation of the maximum principal horizontal stress, $\sigma_{\mathrm{H}}$, according to the second breakdown method, we exclude the pore pressure, and the
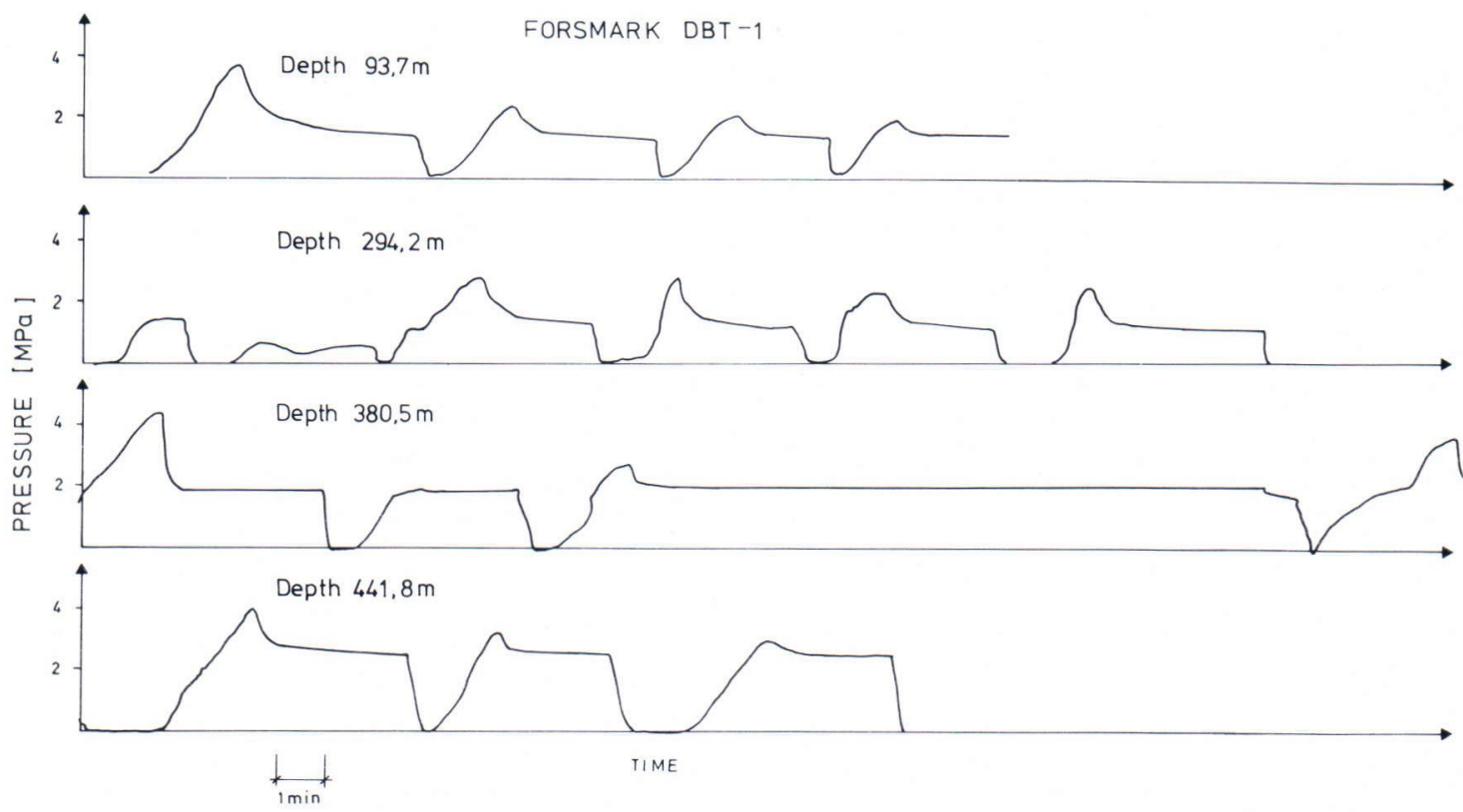

Fig. 8. Pressure-time records from hydraulic fracturing of borehole DBT 1 at Forsmark. 
Table 1. Hydraulic fracturing data and calculated stresses for borehole DBT 1, Forsmark, Sweden.

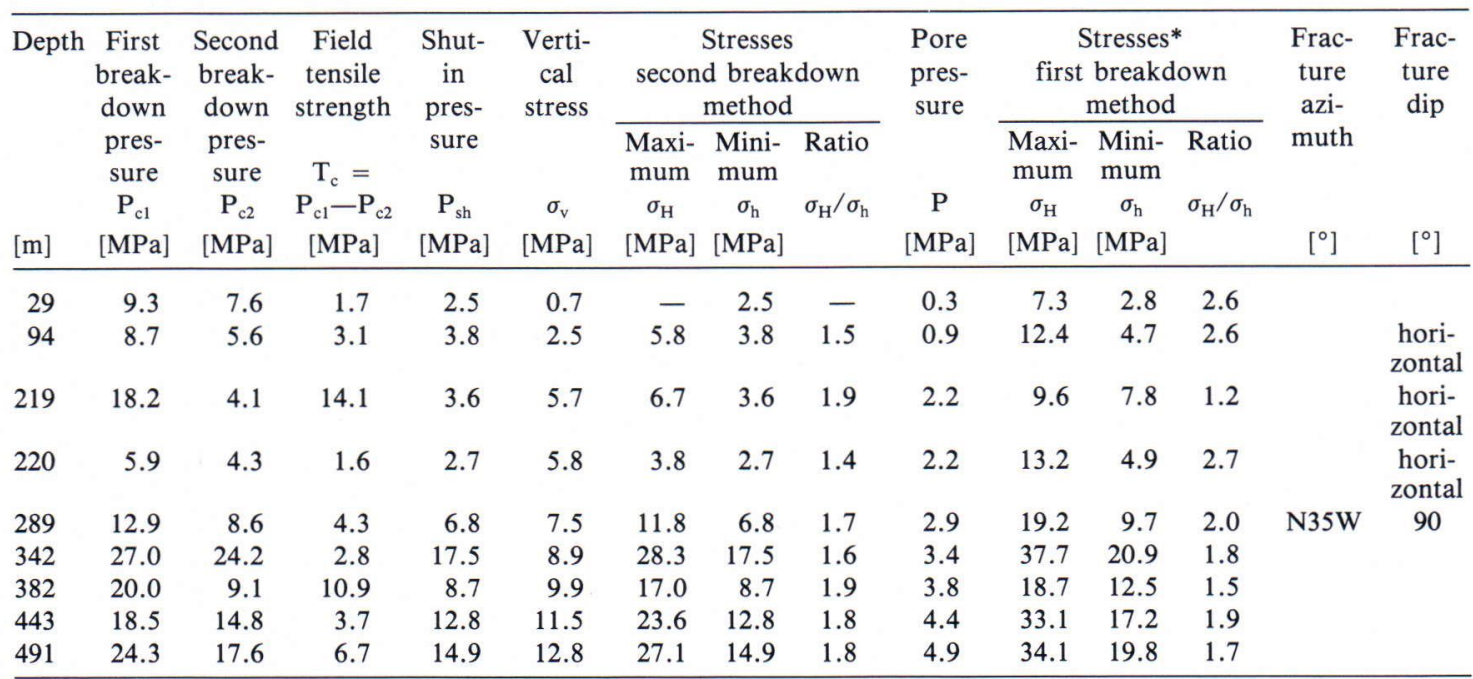

* Reduced laboratory tensile strength, $\mathrm{T}_{\mathrm{o}}=8.8 \mathrm{MPa}$

fracture strength is taken from the field tensile strength (see Table 1). The results show the same trend as for the minimum horizontal stress. Values of the ratio, $\sigma_{\mathrm{H}} / \sigma_{\mathrm{h}}$, are presented in Table 1 . They are plotted as a function of depth in Fig. 9.

Evaluation of the stress state according to the first breakdown method requires determination of the tensile strength, $\mathrm{T}$ in equation (1). From laboratory tests and an estimated reduction due to the larger volume involved for the borehole, the tensile strength was estimated to be $\mathrm{T}=8.8$ $\mathrm{MPa}$, cf. chapter 3. This value is about 30 percent higher than the average value, $T_{c}$, obtained from field tests (see Table 1). Hence, the relatively large value of the applied tensile strength, and the additional hydraulic head, give a larger maximum horizontal principal stress. However, in other respects, the trend is similar to that obtained from the second breakdown method $c f$. Fig. 9. The ratio $\sigma_{\mathrm{H}} / \sigma_{\mathrm{h}}$ also tends to be very large near the surface, but subsequently becomes very close to the ratio obtained from evaluation according to the second breakdown method.

Fracture orientations were obtained using an impression packer in conjunction with a compass mounted on a TV-camera. We were only success- ful in obtaining five impressions down to a depth of less than $300 \mathrm{~m}$. The packer element then malfunctioned and had to be removed from the borehole. For the uppermost 200 meters we found horizontal fractures. This agrees with the calculated stresses, since $\sigma_{\mathrm{h}}$ is less than the weight of the overburden, $c f$. Table 1 .

At a depth of $289 \mathrm{~m}$ we were able to record a vertical impression with a fracture azimuth, and hence the direction of the maximum principal stress was $\mathrm{N} 35^{\circ} \mathrm{W}$.

\section{Results of overcoring stress measurements}

A full description, and results of the overcoring stress measurements with the Swedish State Power Board technique is given by Martna et al. (1983) and the Swedish State Power Board (1982). The measurements were performed at different measuring levels along the borehole with a distance of about 30 to $40 \mathrm{~m}$. At each level one, two or three consecutive recordings and overcorings were made. The results show that the minimum principal stress is approximately vertical, while the intermediate and major principal stresses lie approximately in the horizontal plane 


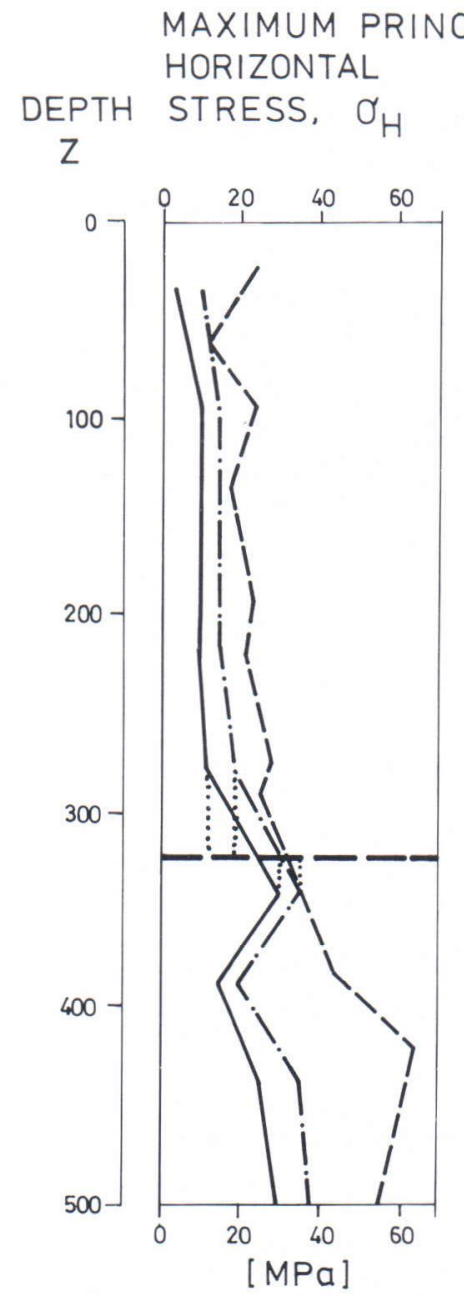

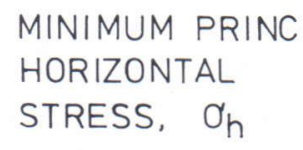

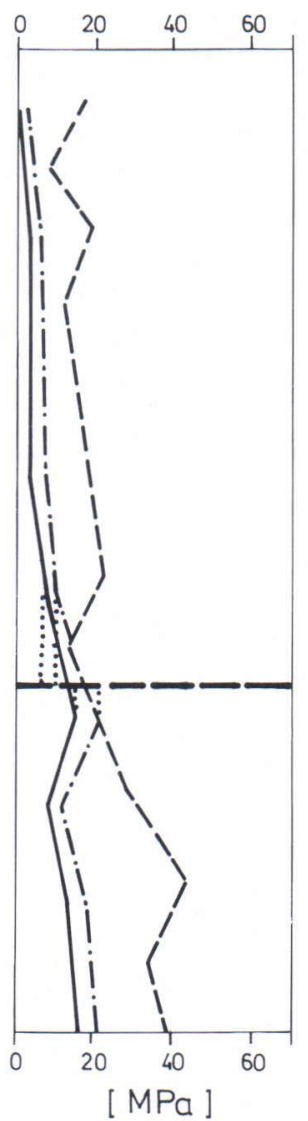

VERTICAL

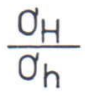

STRESS,

$\sigma_{V}$
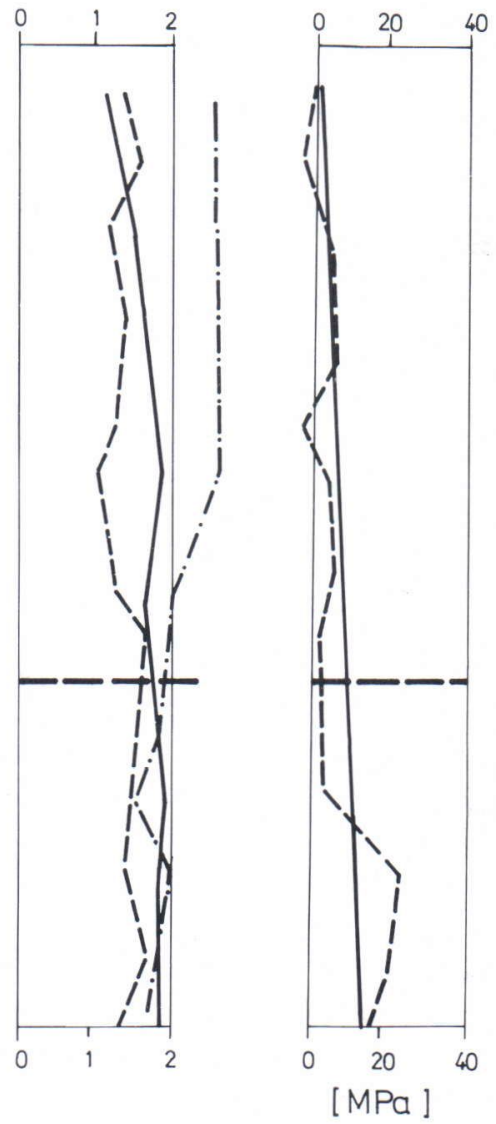

- HYDRAULIC FRACTURING, SECOND BREAK DOWN

-.- - HYDRAULIC FRACTURING, FIRST BREAK DOWN

- - - OVERCORING, SWEDISH STATE POWER BOARD

- - FRACTURE ZONE

Fig. 9. Variation with depth of stress magnitudes at Forsmark. Results from hydraulic fracturing and overcoring are shown, and the major fracture zone at $320 \mathrm{~m}$ level is indicated. Results of overcoring stress measurements after Swedish State Power Board (1982).

and perpendicular to the axis of the borehole. There are several local exceptions and notable scatter in the results obtained, but the very high horizontal stresses have been recorded with the same measurement technique from other tests in the Forsmark area. 
The most interesting result obtained by the measurements in the borehole DBT-1 is the abrupt change of the stresses as the borehole penetrates the fracture zone at $320 \mathrm{~m}$ depth. A plot of the stresses with depth from regression curves clearly indicates a major change in absolute values of stresses and an increase in the rate of stress change with depth below the fracture zone, $c f$. Fig. 9. Between the ground surface, and $200 \mathrm{~m}$ depth the maximum principal horizontal stress is directed almost $\mathrm{E}-\mathrm{W}$, while below the fracture zone the stress direction becomes NW-SE. This change in direction is most probably controlled by the existing fracture zone at the depth of $320 \mathrm{~m}$.

When the results from overcoring and hydraulic fracturing measurement techniques are compared, it must be pointed out that the true stress state is unknown and there is no way of knowing which method is correct. This is made even more complicated by the fact that only the secondary principal stresses and their directions can be compared.

The magnitudes of maximum and minimum horizontal stresses determined from hydraulic fracturing are less than those determined from overcoring, irrespective of the method of evaluation of the hydraulic fracturing. Unfortunately the number of measuring points does not permit any regression analysis, but a rough estimate shows the hydraulic fracturing stress to be (on average) about $50 \%$ less than overcoring. Both methods clearly show the change in magnitude below the fracture zone, and a stress discontinuity for the maximum principal horizontal stress of about $20 \mathrm{MPa}$ is likely to appear. The vertical stress is found to be minor stress below the fracture zone, from the hydraulic fracturing measurements. Finally, the orientation of the maximum horizontal stress is best developed for the overcoring. The one successful impression with the hydraulic fracturing gave quite good agreement between the two techniques as the maximum horizontal stress was directed NW-SE.

\section{Stress measurements at Stidsvig, Scania}

The test site at Stidsvig is situated in NW Scania approximately $80 \mathrm{~km}$ north of the town of Malmö (see Figure 10). The area was investigated by SYDGAS in 1982 for possible development of an underground gas storage facility. Three of the ten boreholes in the area were used for borehole stress measurements, i.e. DBH 82-01, DBH 82-02 and borehole DBH 82-03 with an inclination of $60^{\circ}$. The first borehole has a diameter of $76 \mathrm{~mm}$. The two remaining boreholes have a diameter of $56 \mathrm{~mm}$.

\section{Outline of geology and tectonics}

The test site lies on the boundary of the Fennoscandian Shield and within an extensive gneiss complex, the so-called SW Swedish gneiss region, which forms the major part of the Precambrian in SW Sweden. The complex which extends from the county of Värmland to central Scania is, both on a large and a small scale, characterized by a compositional banding between different types of foliated granitoids. The test area is also frequently cut through by diabases. In some areas two generations of pegmatite veining can be found, see for example Lundqvist (1979).

The major part of the SW Swedish gneisses appears to have been formed by intrusive rocks. These range in composition from granitic to tonalitic, Lundqvist (1979). Rb-Sr dating of tonalitic to granodioritic SW Swedish gneisses from the Vänersborg area has given an age of $1700 \mathrm{Ma}$. However, it is uncertain whether this is the age of the intrusion, or of the metamorphism.

Three principal rock types are present in the Stidsvig area:

a) Red gneiss, which has a greyishred to red colour and a distinctive foliation. It usually consists of quartz and feldspar. The rock contains less than $10 \%$ dark minerals, mainly hornblende and biotite. 

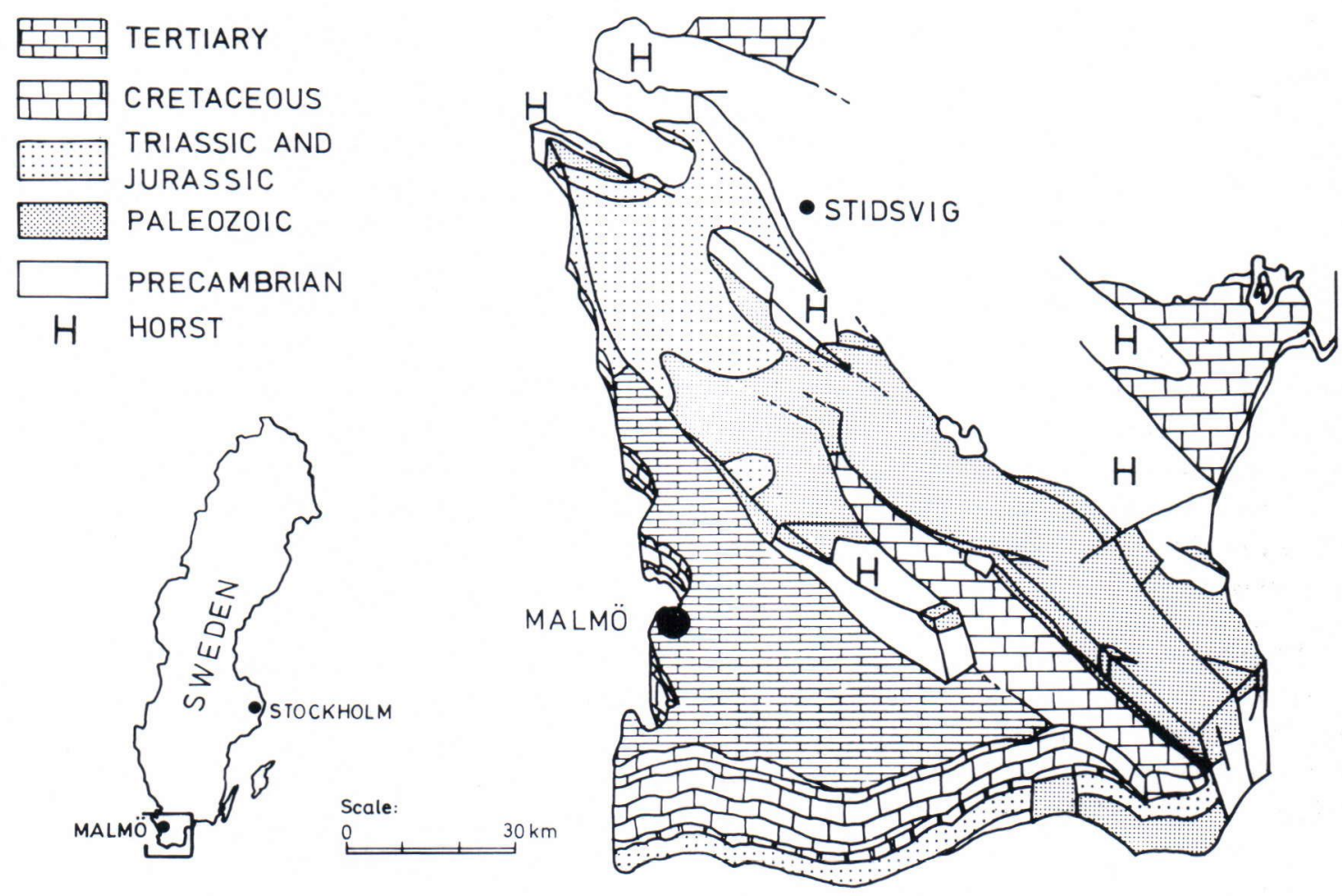

Fig. 10. Location of the test site at Stidsvig, Scania located at the boundary of the Fennoscandian Shield.

b) Supracrustal amphibolites closely related to the gneiss. The rock type is fine grained, with a grey to black colour and a pronounced foliation.

c) Diabase, usually $\mathbf{0}-\mathbf{3}$ meters thick, with minor foliation but typical chilled contacts.

The area has been subjected to extensive tectonic activity. Evidence of this can now be observed by the number of horsts and grabens that dominate the area. The test site is located on the southeastern extension of the so-called Hallandsåsen, which forms a major horst at the boundary of the Fennoscandian Shield.

Two principal fracture sets occur in the area:

a) Steeply dipping fractures striking parallel to the strike of the horst in a NW-SE direction. This is the most important set of joints, and they can be readily observed in this area.

b) A less dominant fracture set, orientated in a NE-SW direction.
The early tectonic history in the area is not completely known. The area has been subjected to deformation at several phases and time periods and in several different directions. Although the geological information from the area is very sparse (partly due to the lack of outcrops) the tectonic activity can, for simplicity, be divided into two stages, Stanfors et al. (1967):

i) Plastic deformation under high temperature and pressure conditions causing foliation. This was due to compressive stresses with a principal orientation in a NE-SW direction, but at later stages also in other directions.

ii) Brittle deformation during later time periods, up to Tertiary, in which the crust was subjected to tensile strains in a SW-NE direction. This extension, and extensive faulting caused diabase intrustion with a NW-SE direction. 
Results of hydraulic fracturing

\section{stress measurements}

From the drill core examinations it was clear that the rock mass at Stidsvig was fractured, and of rather poor quality, i.e. large portions of the cores show RQD-values of 50. It was difficult to find good test sections, at least $500 \mathrm{~mm}$ long, that were free from preexisting fractures and joints. This was expecially difficult at depths less than $75 \mathrm{~m}$. The recorded value of the hydraulic conductivity was $6.5 \cdot 10^{-6} \mathrm{~m} / \mathrm{s}$ below $90 \mathrm{~m}$ in DBH 82-01. Occationally, sections with conductivities of $10^{-9}-10^{-10} \mathrm{~m} / \mathrm{s}$ were found in the boreholes, and these were selected for hydraulic fracturing.

Typical recordings of the pressure-time relationship are shown in Fig. 11. Here we notice the progressive drop in pressure, as the pumps were shut off. Hence, it was difficult to define proper shut-in pressures.

Results of hydraulic fracturing and calculated stresses are presented in Tables 2, 3 and 4. The first breakdown pressure is found to increase with depth, in a fairly uniform manner, and in particular for DBH 82-02. However, there are sections where the fracturing pressures differ from this general trend. A similar situation applies to the second breakdown pressure. With few exceptions, the calculated field tensile strength, $T_{c}$, is very low. This supports the idea that the bedrock is a jointed rock mass with good interaction between the existing joints. There is a tendency for the field tensile strengths to have a minimum at DBT 82-01, and a maximum at DBT 82-03. However, average of $\mathrm{T}_{\mathrm{c}}=1.8 \mathrm{MPa}$ and the maximum values at the greatest depths for each of the boreholes tested are considered representative. The lowest value in strength for borehole DBT 82-01 may reflect the influence of borehole size.

The vertical stress is presented as the weight of the overburden, i.e. the effect of the inclination of borehole DBH 82-03 was considered in the calculation of $\sigma_{\mathrm{v}}$ in Table 4. Maximum and minimum horizontal principal stresses have been calculated according to the two methods of first and second breakdown. An application of the second breakdown method, equation (2), to the data for DBH 82-01 gave $\sigma_{\mathrm{H}^{-}}$-values less than $\sigma_{\mathrm{h}}$ values, and for three of the tested sections, even a negative value for the maximum principal stress was obtained. Only five of the thirteen sections tested gave a ratio $\sigma_{\mathrm{H}} / \sigma_{\mathrm{h}}>1$. This again casts some doubts on the validity of the method of calculating the stresses according to the second breakdown method (i.e. water pressure is neglected. Accounting for the pore pressure which is assumed to be the water head in the borehole and applying the first breakdown method according to equation (1), we eliminate the problem of negative values of $\sigma_{\mathrm{H}}$, and $\sigma_{\mathrm{H}} / \sigma_{\mathrm{h}}$ ratios less than one, cf. Table 2. On the other hand, we have to use a much larger value of the tensile strength, $\mathrm{T}_{\mathrm{o}}$, which is based on laboratory tests on intact rock samples, i.e. 8.5 $\mathrm{MPa}$ for the gneiss and 12.2 MPa for the amphibolite. To be correct, the values for the $56 \mathrm{~mm}$ boreholes should be even larger. However, at this stage of the study where only one series of samples was tested in the laboratory, we have kept the same value for all the boreholes. The method of introducing the tensile strength of intact rock samples and the pore pressure gives large magnitudes of stresses, increasing stresses with depth and finally large $\sigma_{\mathrm{H}} / \sigma_{\mathrm{h}}$-ratios at the surface and an almost constant value of about 2 at depth below $120 \mathrm{~m}$.

The calculated stresses according to the first breakdown method are presented in Tables 2, 3 and 4 and plotted in Fig. 12. The increase in $\sigma_{\mathrm{H}}$ and $\sigma_{\mathrm{h}}$ with depth is clear as also is the decrease in $\sigma_{\mathrm{H}} / \sigma_{\mathrm{h}}$ with depth. A regression analysis for the measurements at Stidsvig gives the following relations:

$$
\begin{aligned}
& \sigma_{\mathrm{H}}=7.12+4.34 \cdot 10^{-2} \cdot \mathrm{z} \\
& \sigma_{\mathrm{h}}=0.53+3.78 \cdot 10^{-2} \cdot \mathrm{z} \\
& \sigma_{\mathrm{H}} / \sigma_{\mathrm{v}}=5.34-2.21 \cdot 10^{-2} \cdot \mathrm{z}
\end{aligned}
$$

Notice that the data for the inclined borehole is included in equations (5), (6) and (7). These 

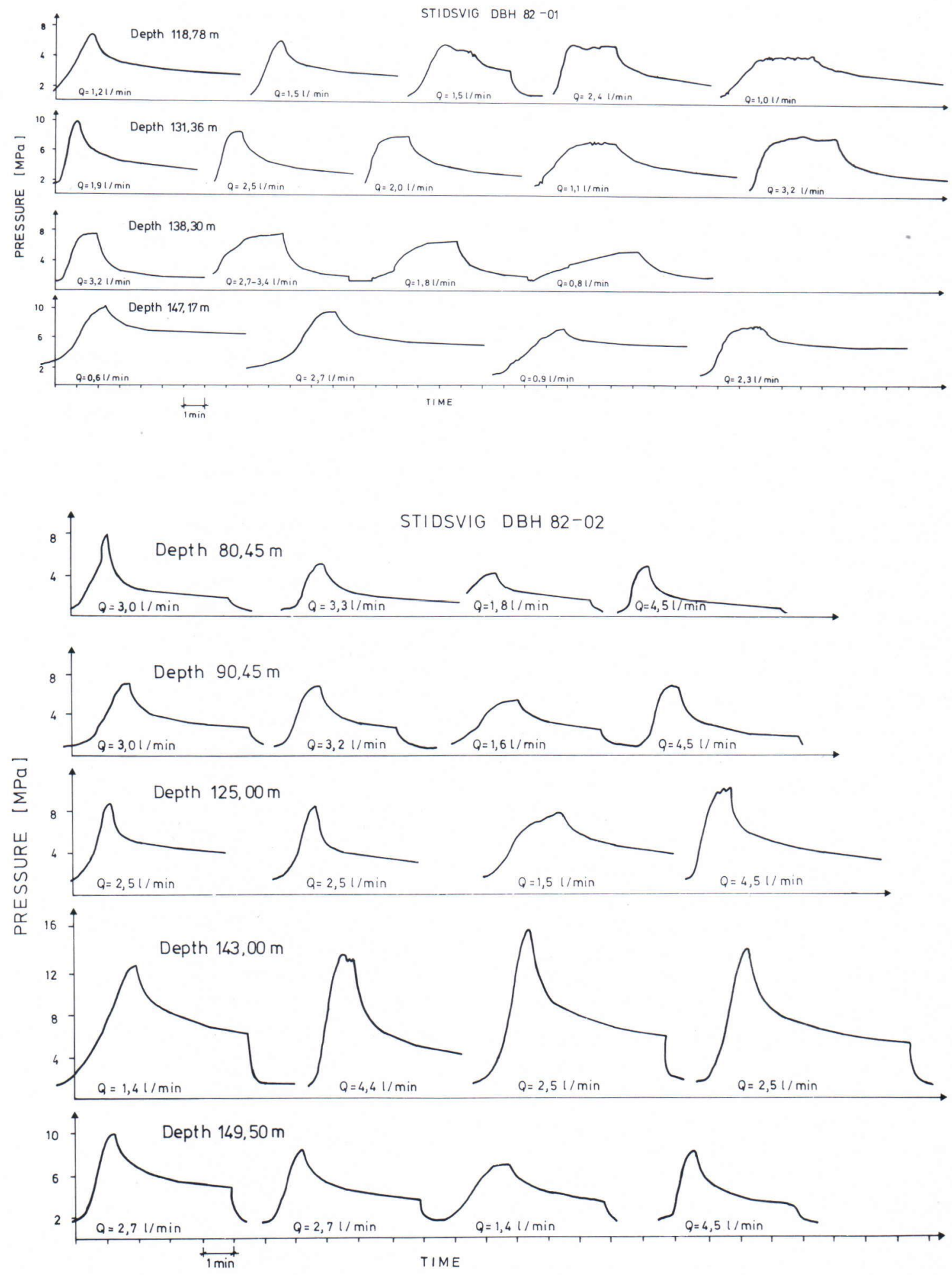

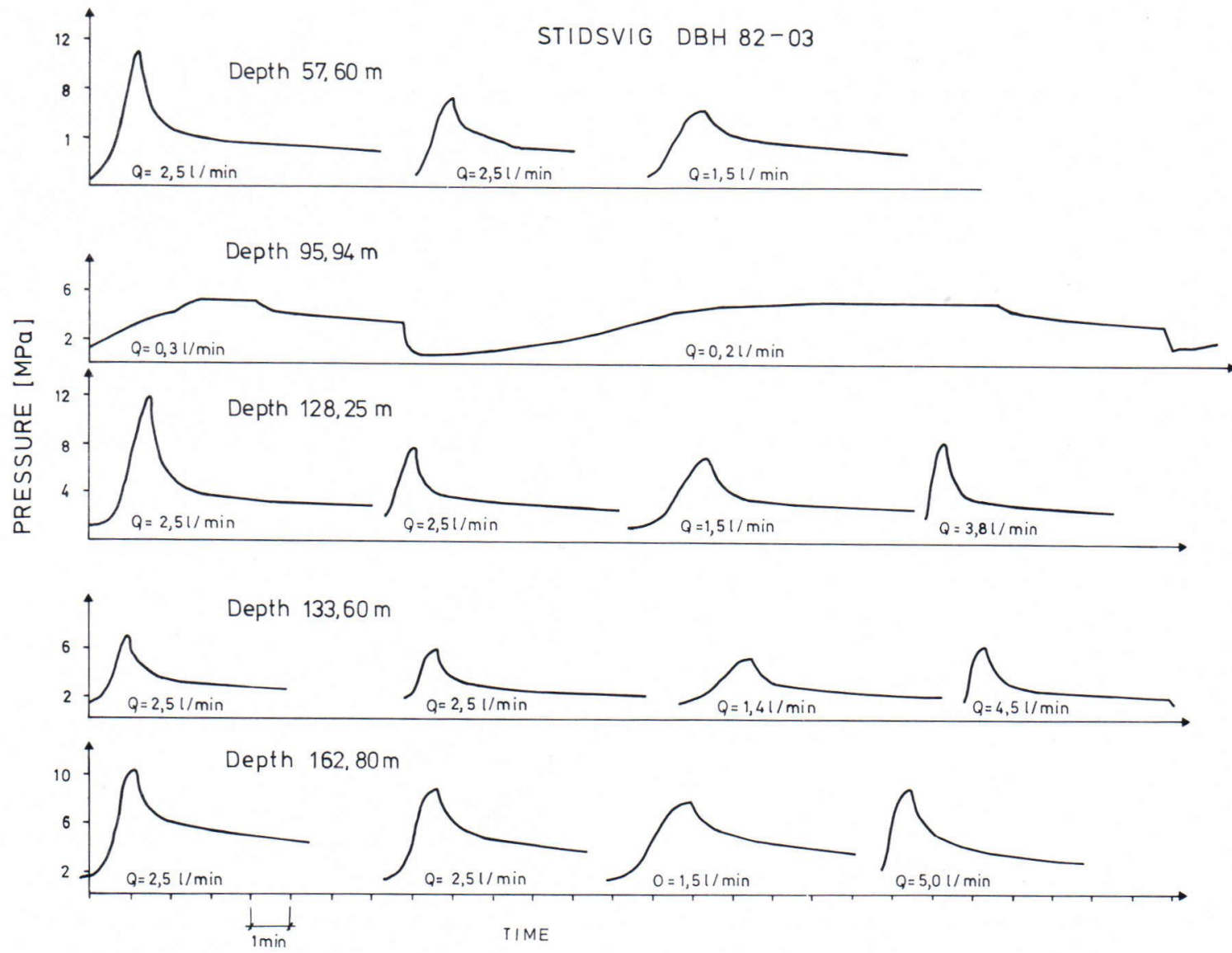

Fig. 11. Recording of pressure versus time for selected test sections in the boreholes at Stidsvig.

relationships are, in principle, in agreement with existing data for stress changes with depth in the Precambrian rocks of Sweden, $c f$. Leijon et al. (1980) and Doe et al. (1983 b).

Fracture impressions and orientations were taken only at five or six sections in each borehole. In the vertical borehole DBH 82-01, the fracture impressions were successful only at one test section at 118.8 meters. A well defined fracture plane could be observed. This indicated a maximum horizontal stress direction of $\mathrm{N} 30^{\circ} \mathrm{E}-\mathrm{S} 30^{\circ}$.

The fracture impressions in the other vertical borehole, DBH 82-02, shows that the same trend is valid with some reorientation of the maximum principal stress to the east, as indicated by the impression at 138.0 meters, see Table 3 .

The fracture impressions in the inclined borehole, DBH 82-03, were very difficult to interpret. The fracture orientations were very complex and showed no definite pattern, and the number of fractures made the analysis impossible. Theoretical studies by Richardson (1983) and experimental results obtained by Daneshy (1973) indicate that large errors are possible in inferring that the hydraulic fracture is normal to the least compressive stress direction, when the borehole is arbirarely oriented. Thus, the fracture impressions in borehole DBH 82-03 have not been used for determination of the principal stress directions. 
Table 2. Hydraulic fracturing data and calculated stresses for borehole DBH 82-01, diameter 76 mm, Stidsvig, Sweden.

\begin{tabular}{|c|c|c|c|c|c|c|c|c|c|c|c|c|c|c|c|}
\hline \multirow{2}{*}{$\begin{array}{l}\text { Depth } \\
{[\mathrm{m}]} \\
\end{array}$} & \multirow[t]{2}{*}{$\begin{array}{l}\text { Rock } \\
\text { type }\end{array}$} & \multirow{2}{*}{$\begin{array}{c}\text { First } \\
\text { break- } \\
\text { down } \\
\text { pres- } \\
\text { sure } \\
\mathrm{P}_{\mathrm{cl}} \\
{[\mathrm{MPa}]}\end{array}$} & \multirow{2}{*}{$\begin{array}{c}\text { Second } \\
\text { break- } \\
\text { down } \\
\text { pres- } \\
\text { sure } \\
\mathrm{P}_{\mathrm{c} 2} \\
{[\mathrm{MPa}]}\end{array}$} & \multirow{2}{*}{$\begin{array}{c}\text { Field } \\
\text { tensile } \\
\text { strength } \\
\mathrm{T}_{\mathrm{c}}= \\
\mathrm{P}_{\mathrm{cl}-\mathrm{P}_{\mathrm{c} 2}} \\
{[\mathrm{MPa}]}\end{array}$} & \multirow{2}{*}{$\begin{array}{l}\text { Shut- } \\
\text { in } \\
\text { pres- } \\
\text { sure } \\
\\
\mathrm{P}_{\text {sh }} \\
{[\mathrm{MPa}]}\end{array}$} & \multirow{2}{*}{$\begin{array}{l}\text { Verti- } \\
\text { cal } \\
\text { stress } \\
\\
\\
\sigma_{\mathrm{v}} \\
{[\mathrm{MPa}]}\end{array}$} & \multicolumn{3}{|c|}{$\begin{array}{c}\text { Stresses } \\
\text { second breakdown } \\
\text { method } \\
\end{array}$} & \multirow{2}{*}{$\begin{array}{c}\text { Pore } \\
\text { pres- } \\
\text { sure } \\
\\
\text { P } \\
{[\mathrm{MPa}]}\end{array}$} & \multicolumn{3}{|c|}{$\begin{array}{c}\text { Stresses* } \\
\text { first breakdown } \\
\text { method }\end{array}$} & \multirow{2}{*}{$\begin{array}{c}\text { Frac- } \\
\text { ture } \\
\text { azi- } \\
\text { muth } \\
\\
\left.{ }^{\circ}\right]\end{array}$} & \multirow{2}{*}{$\begin{array}{c}\text { Frac- } \\
\text { ture } \\
\text { dip } \\
\\
{\left[^{\circ}\right]}\end{array}$} \\
\hline & & & & & & & $\begin{array}{c}\text { Maxi- } \\
\text { mum } \\
\sigma_{\mathrm{H}} \\
{[\mathrm{MPa}]}\end{array}$ & $\begin{array}{c}\text { Mini- } \\
\text { mum } \\
\sigma_{\mathrm{h}} \\
{[\mathrm{MPa}]}\end{array}$ & $\begin{array}{l}\text { Ratio } \\
\sigma_{\mathrm{H}} / \sigma_{\mathrm{h}}\end{array}$ & & $\begin{array}{c}\text { Maxi- } \\
\text { mum } \\
\sigma_{\mathrm{H}} \\
{[\mathrm{MPa}]}\end{array}$ & $\begin{array}{c}\text { Mini- } \\
\text { mum } \\
\sigma_{\mathrm{h}} \\
{[\mathrm{MPa}]}\end{array}$ & $\begin{array}{l}\text { Ratio } \\
\sigma_{\mathrm{H}} / \sigma_{\mathrm{h}}\end{array}$ & & \\
\hline 60.5 & gneiss & 4.4 & 3.8 & 0.6 & 1.4 & 1.5 & 0.4 & 1.4 & 0.3 & 0.6 & 8.9 & 2.0 & 4.5 & (N70E) & (70SE) \\
\hline 64.5 & $»$ & 1.6 & 1.3 & 0.3 & 0.7 & 1.7 & 0.8 & 0.7 & 1.1 & 0.6 & 9.6 & 1.3 & 7.4 & & \\
\hline 75.9 & $"$ & $\mathrm{OP}$ & EN FR & ACTURES & $5-$ & 2.0 & & & & 0.7 & & & & & \\
\hline 93.1 & $»$ & OP & EN FR & ACTURES & $5-$ & 2.4 & & & & 0.9 & & & & & \\
\hline 96.8 & $»$ & 6.3 & 5.4 & 0.8 & 2.2 & 2.5 & 1.1 & 2.2 & 0.5 & 0.9 & 9.7 & 3.1 & 3.1 & (N15E) & $(70 \mathrm{NM}$ \\
\hline 108.9 & $»$ & 5.4 & 5.4 & 0 & 1.3 & 2.8 & - & 1.3 & - & 1.1 & 8.1 & 2.4 & 3.4 & & \\
\hline 118.8 & $»$ & 9.0 & 8.0 & 1.0 & 5.0 & 3.1 & 7.0 & 5.0 & 1.4 & 1.1 & 15.6 & 6.1 & 2.6 & $\mathrm{~N} 30 \mathrm{E}$ & 90 \\
\hline 131.4 & $»$ & 9.9 & 8.5 & 1.4 & 4.6 & 3.4 & 5.3 & 4.6 & 1.2 & 1.3 & 13.7 & 5.9 & 2.3 & (N70E) & $(85 \mathrm{~N})$ \\
\hline 134.0 & $"$ & 8.0 & 8.0 & 0 & 2.4 & 3.5 & - & 2.4 & - & 1.3 & 9.0 & 3.7 & 2.4 & & \\
\hline 138.3 & $"$ & 8.5 & 8.1 & 0.4 & 2.5 & 3.6 & - & 2.5 & - & 1.4 & 8.9 & 3.9 & 2.3 & & \\
\hline 142.0 & $»$ & $\mathrm{OP}$ & EN FR & ACTURES & - & 3.7 & & & & 1.4 & & & & & \\
\hline 144.9 & $"$ & 9.9 & 8.5 & 1.4 & 4.3 & 3.7 & 4.4 & 4.3 & 1.0 & 1.4 & 12.9 & 5.7 & 2.3 & & \\
\hline 147.2 & $\begin{array}{l}\text { am- } \\
\text { phibo- } \\
\text { lite }\end{array}$ & 10.0 & 7.4 & 2.6 & 5.7 & 3.8 & 7.3 & 5.7 & 1.7 & 1.5 & 20.8 & 7.2 & 2.9 & (N80E) & $(85 \mathrm{~N})$ \\
\hline
\end{tabular}

* Reduced laboratory tensile strength $\begin{aligned} & \text { gneiss, } \mathrm{T}_{\mathrm{o}}=8.5 \mathrm{MPa} \\ & \text { amphibolite, } \mathrm{T}_{\mathrm{o}}=12.2 \mathrm{MPa}\end{aligned}$

Table 3. Hydraulic fracturing data and calculated stresses for borehole DBH 82-02, diameter 56 mm, Stidsvig, Sweden.

\begin{tabular}{|c|c|c|c|c|c|c|c|c|c|c|c|c|c|c|c|}
\hline \multirow{2}{*}{$\begin{array}{l}\text { Depth } \\
{[\mathrm{m}]} \\
\end{array}$} & \multirow[t]{2}{*}{$\begin{array}{l}\text { Rock } \\
\text { type }\end{array}$} & \multirow{2}{*}{$\begin{array}{c}\text { First } \\
\text { break- } \\
\text { down } \\
\text { pres- } \\
\text { sure } \\
\mathrm{P}_{\mathrm{cl}} \\
{[\mathrm{MPa}]}\end{array}$} & \multirow{2}{*}{$\begin{array}{l}\text { Second } \\
\text { break- } \\
\text { down } \\
\text { pres- } \\
\text { sure } \\
P_{c 2} \\
{[\mathrm{MPa}]}\end{array}$} & \multirow{2}{*}{$\begin{array}{c}\text { Field } \\
\text { tensile } \\
\text { strength } \\
\mathrm{T}_{\mathrm{c}}= \\
\mathrm{P}_{\mathrm{c} 1}-\mathrm{P}_{\mathrm{c} 2} \\
{[\mathrm{MPa}]}\end{array}$} & \multirow{2}{*}{$\begin{array}{l}\text { Shut- } \\
\text { in } \\
\text { pres- } \\
\text { sure } \\
\mathrm{P}_{\text {sh }} \\
{[\mathrm{MPa}]}\end{array}$} & \multirow{2}{*}{$\begin{array}{c}\text { Verti- } \\
\text { cal } \\
\text { stress } \\
\\
\\
\sigma_{\mathrm{v}} \\
{[\mathrm{MPa}]}\end{array}$} & \multicolumn{3}{|c|}{$\begin{array}{c}\text { Stresses } \\
\text { second breakdown } \\
\text { method } \\
\end{array}$} & \multirow{2}{*}{$\begin{array}{c}\text { Pore } \\
\text { pres- } \\
\text { sure } \\
\\
\mathrm{P} \\
{[\mathrm{MPa}]}\end{array}$} & \multicolumn{3}{|c|}{$\begin{array}{c}\text { Stresses* } \\
\text { first breakdown } \\
\text { method }\end{array}$} & \multirow{2}{*}{$\begin{array}{c}\text { Frac- } \\
\text { ture } \\
\text { azi- } \\
\text { muth } \\
\\
\left.{ }^{\circ}\right]\end{array}$} & \multirow{2}{*}{$\begin{array}{c}\text { Frac- } \\
\text { ture } \\
\text { dip } \\
\\
\left.{ }^{\circ}\right]\end{array}$} \\
\hline & & & & & & & $\begin{array}{c}\text { Maxi- } \\
\text { mum } \\
\sigma_{\mathrm{H}} \\
{[\mathrm{MPa}]}\end{array}$ & $\begin{array}{c}\text { Mini- } \\
\text { mum } \\
\sigma_{\mathrm{h}} \\
{[\mathrm{MPa}]}\end{array}$ & $\begin{array}{l}\text { Ratio } \\
\sigma_{\mathrm{H}} / \sigma_{\mathrm{h}}\end{array}$ & & $\begin{array}{c}\text { Maxi- } \\
\text { mum } \\
\sigma_{\mathrm{H}} \\
{[\mathrm{MPa}]}\end{array}$ & $\begin{array}{c}\text { Mini- } \\
\text { mum } \\
\sigma_{\mathrm{h}} \\
{[\mathrm{MPa}]}\end{array}$ & $\begin{array}{l}\text { Ratio } \\
\sigma_{\mathrm{H}} / \sigma_{\mathrm{h}}\end{array}$ & & \\
\hline 17.5 & gneiss & 3.9 & 2.9 & 1.0 & 1.1 & 0.4 & 0.4 & 1.1 & 0.4 & 0.2 & 8.1 & 1.3 & 6.2 & & \\
\hline 29.3 & $»$ & 5.0 & 4.8 & 0.2 & 1.9 & 0.8 & 0.9 & 1.9 & 0.5 & 0.3 & 9.5 & 2.2 & 4.3 & & \\
\hline 33.8 & " & 3.3 & 3.2 & 0.1 & 1.2 & 0.9 & 0.4 & 1.2 & 0.3 & 0.3 & 9.1 & 1.5 & 6.1 & & \\
\hline 44.4 & $»$ & 7.8 & 4.8 & 3.0 & 1.9 & 1.2 & 0.9 & 1.9 & 0.5 & 0.4 & 6.8 & 2.3 & 3.0 & & \\
\hline 65.1 & $»$ & 7.9 & 7.2 & 0.7 & 3.2 & 1.7 & 2.4 & 3.2 & 0.8 & 0.6 & 10.8 & 3.8 & 2.8 & & \\
\hline 80.5 & $»$ & 8.0 & 5.3 & 2.7 & 2.6 & 2.1 & 2.5 & 2.6 & 1.0 & 0.8 & 9.1 & 3.4 & 2.7 & & \\
\hline 90.5 & $»$ & 6.8 & 6.6 & 0.2 & 3.8 & 2.4 & 4.8 & 3.8 & 1.3 & 0.9 & 14.0 & 4.7 & 3.0 & (N10E) & (90) \\
\hline 109.5 & $»$ & 6.9 & 5.2 & 0.3 & 2.5 & 2.8 & 2.7 & 2.5 & 1.1 & 1.1 & 10.2 & 3.6 & 2.8 & (N70E) & (90) \\
\hline 125.0 & $»$ & 8.9 & 8.4 & 0.5 & 5.2 & 3.3 & 7.2 & 5.2 & 1.4 & 1.3 & 16.5 & 6.5 & 2.5 & $\mathrm{~N} 30 \mathrm{E}$ & 90 \\
\hline 129.3 & $"$ & 6.0 & 5.7 & 0.3 & 2.5 & 3.4 & 1.8 & 2.5 & 0.7 & 1.3 & 11.3 & 3.8 & 2.9 & & \\
\hline 138.0 & $»$ & 12.0 & 6.3 & 5.7 & 4.0 & 3.6 & 5.7 & 4.0 & 1.4 & 1.4 & 9.9 & 5.4 & 1.8 & $\mathrm{~N} 50 \mathrm{E}$ & 90 \\
\hline 143.0 & $"$ & 15.9 & 14.3 & 1.6 & 7.5 & 3.7 & 8.2 & 7.5 & 1.1 & 1.4 & 16.5 & 8.9 & 1.9 & $\begin{array}{l}\text { (N20- } \\
40 \mathrm{E})\end{array}$ & (90) \\
\hline 149.5 & $"$ & 10.2 & 0.0 & 1.6 & 5.7 & 3.9 & 8.5 & 5.7 & 1.5 & 1.5 & 16.9 & 7.2 & 2.3 & (N10E) & (90) \\
\hline 150.5 & $»$ & 19.0 & 13.6 & 5.4 & 6.4 & 3.9 & 10.2 & 6.4 & 1.6 & 1.5 & 10.2 & 7.9 & 1.3 & & \\
\hline
\end{tabular}

* Reducted laboratory tensile strength for gneiss, $\mathrm{T}_{0}=8.5 \mathrm{MPa}$ 
Table 4. Hydraulic fracturing data and calculated stresses for borehole DBH 82-03, inclined $60^{\circ}$, diameter 56 mm, Stidsvig, Sweden.

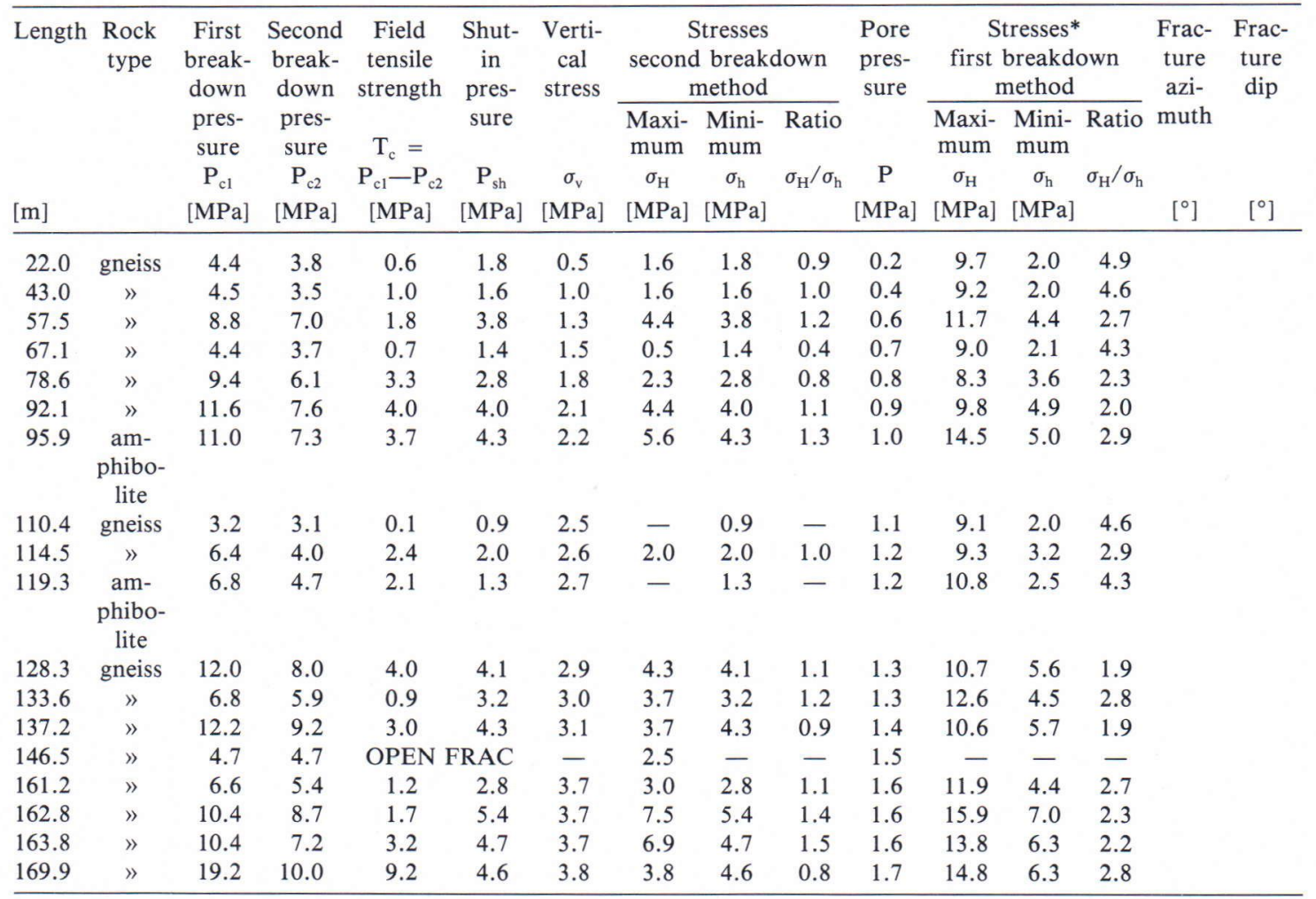

* Reduced laboratory tensile strength $\begin{aligned} & \text { gneiss, } \mathrm{T}_{\mathrm{o}}=8.5 \mathrm{MPa} \\ & \text { amphibolite, } \mathrm{T}_{\mathrm{o}}=12.5 \mathrm{MPa}\end{aligned}$

\section{Results of overcoring stress measurements}

The overcoring stress measurements were conducted in July 1982 by the Swedish State Power Board. Successful measurements were made at three depths, 101.25 meters, 102.32 meters and 103.55 meters respectively in the $76 \mathrm{~mm}$ diameter vertical borehole DBH 82-01. One measurement attempt, at 100.38 meters, failed because of poor contact in electrical circuits. Difficulties were encountered with the poor quality rock in the borehole. Hence, only two of the core samples could be used for determination of the elastic parameters. The strain data were evaluated by including and also neglecting the effects of the water pressure in the borehole, $c f$. Table 5. As pointed out by Strindell and Anderson (personal communication), the stress distribution, with $\sigma_{1}$ beeing almost vertical, and about three times the overburden pressure, is very unusual. It is due principally, to the shallow depth and the jointed rock mass. The calculated tensile stress, $\sigma_{3}=-0.6 \mathrm{MPa}$, becomes compressive, $\sigma_{3}=$ $0.2 \mathrm{MPa}$ since the water pressure in the borehole is included in the calculations, $c f$. Table 5.

There is very little agreement in the results obtained from overcoring and hydraulic fracturing stress measurements. To some extent, this is due to differences in measuring technique and evaluation. Hence, the large vertical stress obtained from overcoring cannot be compared with the results of hydraulic fracturing, since vertical stresses are assumed to be the weight of the over- 

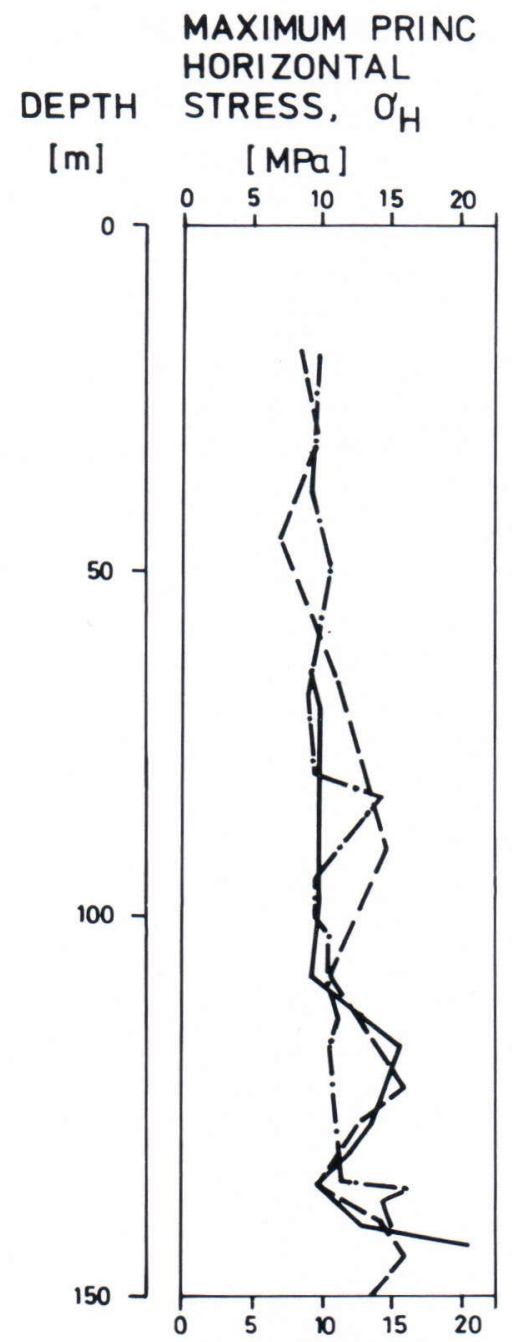
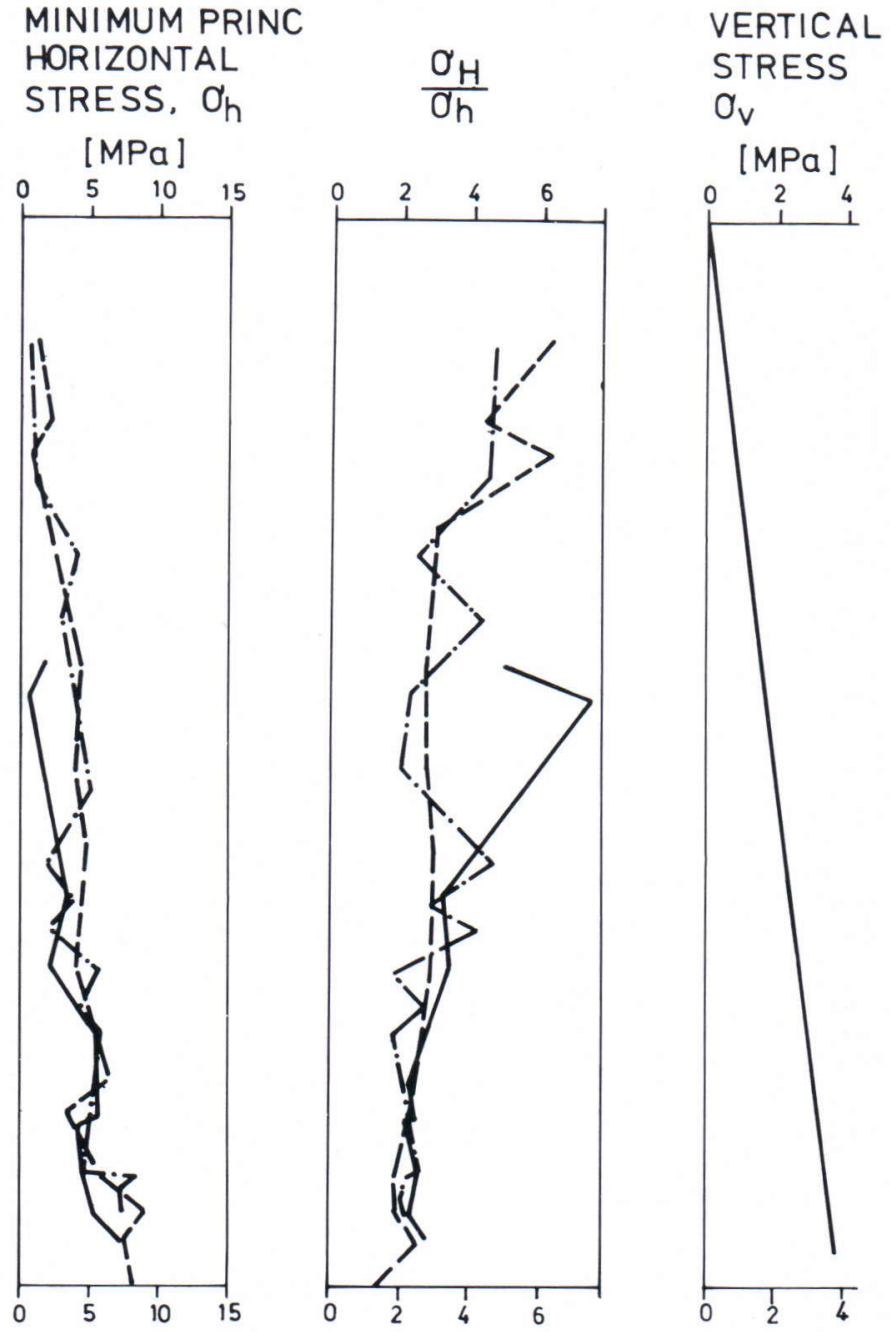

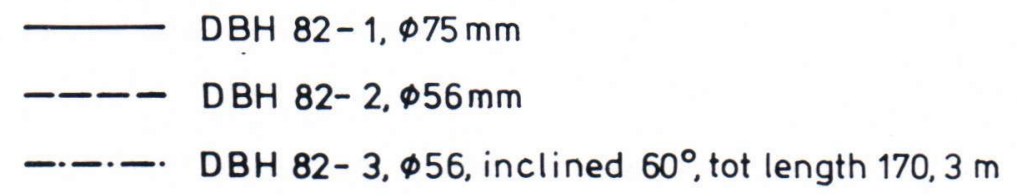

Fig. 12. Calculated stresses according to the first breakdown method as a function of depth for three boreholes at Stidsvig.

burden. The very low magnitude in horizontal stress at the depth of about one hundred meters with the overcoring technique is not supported by the results from hydraulic fracturing, irrespec- tive of the two methods of evaluation. There seems to be an agreement in the direction of $\mathrm{N} 30^{\circ} \mathrm{E}-\mathrm{S} 30^{\circ} \mathrm{W}$ for the maximum principal stress in borehole DBH 82-01. 


\section{Conclusion}

Determination of the virgin stress state in the Earth's crust from hydraulic fracturing data is not as straightforward as the simple theory would predict. Although the hydrofracturing technique is well developed, the underlying theory is still poorly understood. At the same time, there are an increasing number of studies advocating that the stresses determined by hydrofracturing and overcoring are basically in general agreement, Haimson (1983) and Doe et al. (1983 b). This study clearly demonstrates that agreement for hydrofracturing and overcoring measurements depend heavily on which methods are used to evaluate the hydraulic fracturing data. In our study we reached the following conclusions:

1) The new development of a hydraulic fracturing stress measurement system, based on a multi-hose and special connections for the downhole tools operated very satisfactorily. Air-powered pumps, regulators for maintaining a constant differential pressure for fracturing, and the packers require further development, as does the borehole TVcamera.

2) Repeated pressurization was conducted at each test zone to pick up successive breakdown and shut-in pressures. Shut-in pressures were obtained by plotting the pressure-time curve on semilogarithmic diagrams. Slow pumping until the pressure is just sufficient to open the fracture was applied to obtain an improved definition of the value of the shutin pressure for one of the test zones. The breakdown pressures were clearly defined and easily determined from the pressure-time curves.

3) We found that the calculated principal horizontal stresses are most sensitive to the method of analyzing hydrofracture data. First and second breakdown methods were applied to the pressure-time recordings at Forsmark and Stidsvig. The large differences in calculated stresses obtained from each method prove the necessesity of presenting the raw data for borehole in a hydrofracturing campain.

4) The maximum and minimum horizontal stresses at Forsmark increase with depth as shown in Fig. 9. Calculated stresses according to the second breakdown method, where the field tensile strength from the first and second breakdown and zero pore pressure were used, gave the stresses of the smallest magnitude. The good rock mass quality, with an average of two fractures per meter, and the low conductivity of $10^{-10} \mathrm{~m} / \mathrm{s}$ speak in favour of stress evaluation according to the second breakdown method. By using a linear regression analysis of the hydrofracturing data, the discontinuity of the stress field in the vicinity of the fracture zone at $320 \mathrm{~m}$ depth can be proved. However, without knowing the existance of the fracture zone, it would have been difficult to prescribe its existance from the stress measurement results.

5) The calculated maximum and minimum horizontal stresses at Stidsvig also increase with depth as shown in Fig. 12. Calculated stresses, based on the second breakdown method gave several incorrect results for the $\sigma_{\mathrm{H}} / \sigma_{\mathrm{h}}$-ratios, and in some cases negative stresses. The poor rock mass quality at Stidsvig, with an average RQD of $50 \%$, and a rock mass conductivity exceeding $10^{-7} \mathrm{~m} / \mathrm{s}$, speak in favour of a stress evaluation according to the first breakdown method. Laboratory tensile strength tests of the rock were run on core samples, and the data were reduced by $50 \%$ to account for the larger boreholes used in the field. The direction of the maximum principal horizontal stress is found to be NE-SW. This is contrary to the general trend of NW-SE directed horizontal stress for large areas of northern Europe. The location of the test site close to the boundary of the Fennoscandian Shield, and the typical horst and graben structures in the area probably 
DBH 82-01

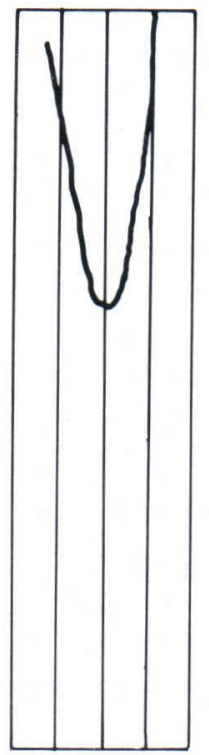

E N W 48. $6 \mathrm{~m}$
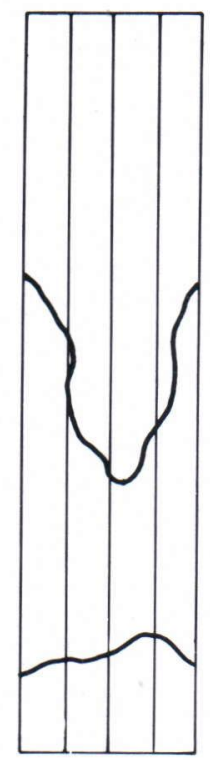

$N$ W S EN $62.1 \mathrm{~m}$

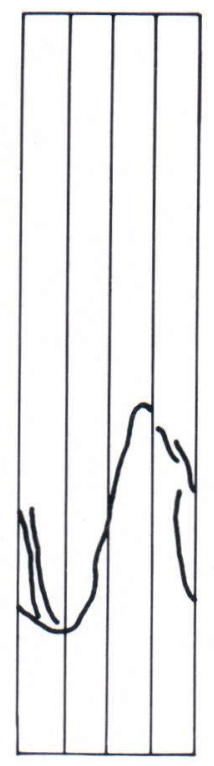

$N W S E N$ $96.8 \mathrm{~m}$
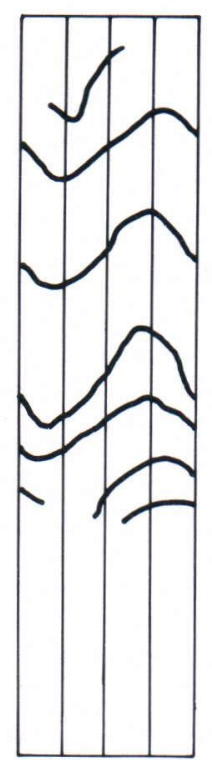

$N$ W S N $98.6 \mathrm{~m}$

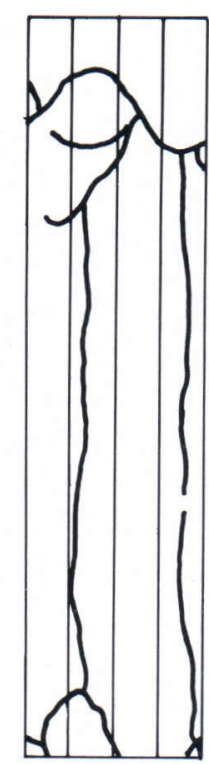

$N$ W S N $118.7 \mathrm{~m}$

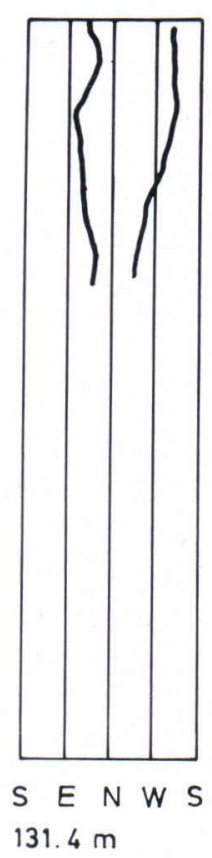

DBH 82-02

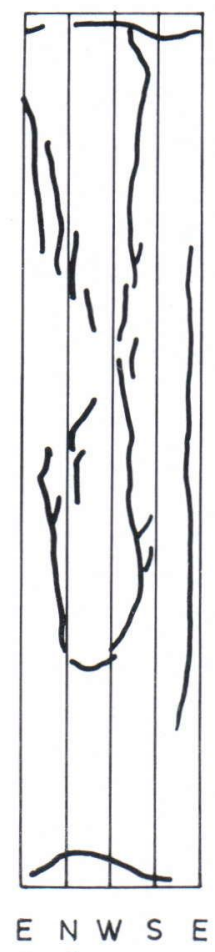

$90.5 \mathrm{~m}$

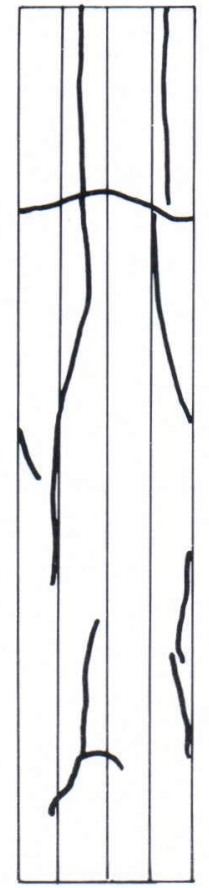

$N W S E N$ $125.0 \mathrm{~m}$

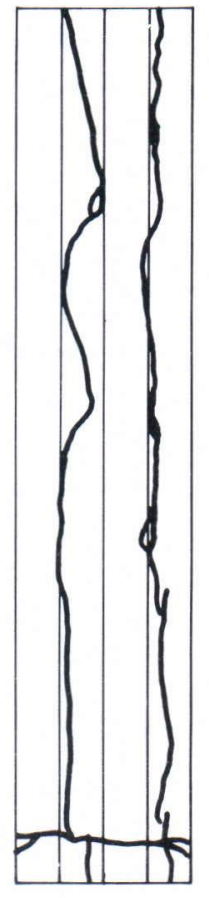

$S E N W S$ $138.0 \mathrm{~m}$

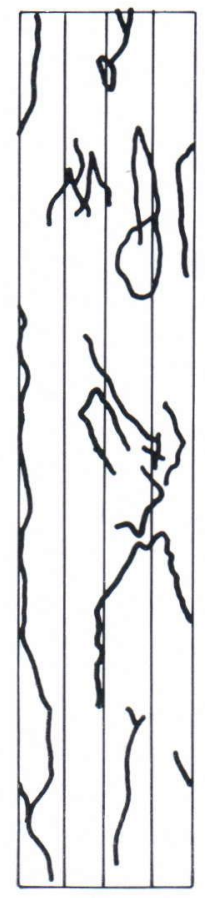

E NW S E $143.0 \mathrm{~m}$

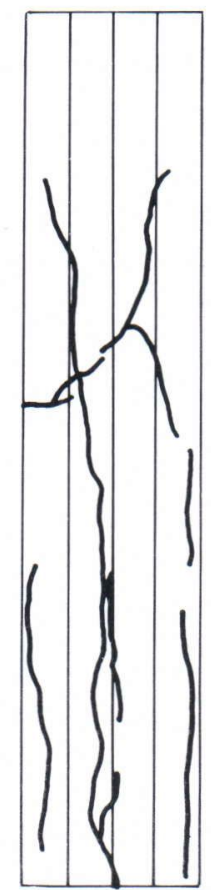

$N E S W N$ $149.5 \mathrm{~m}$ 
DBH 82-03

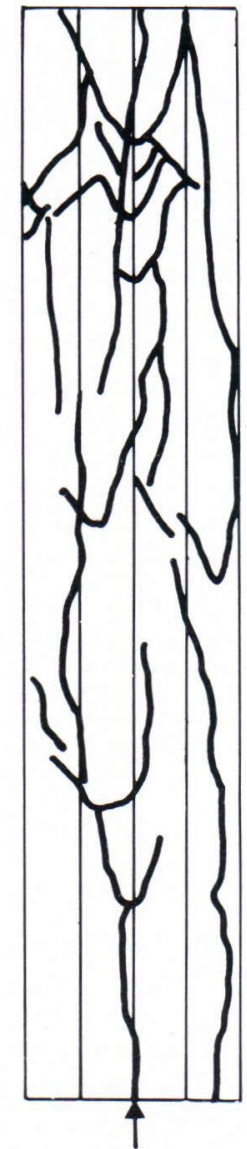

$57.6 \mathrm{~m}$

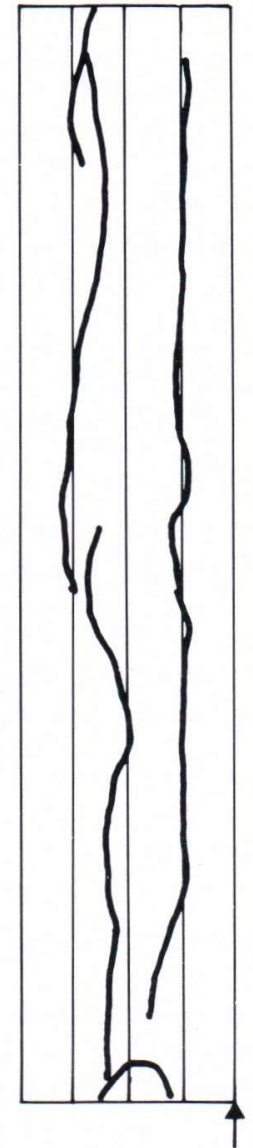

$95.9 \mathrm{~m}$

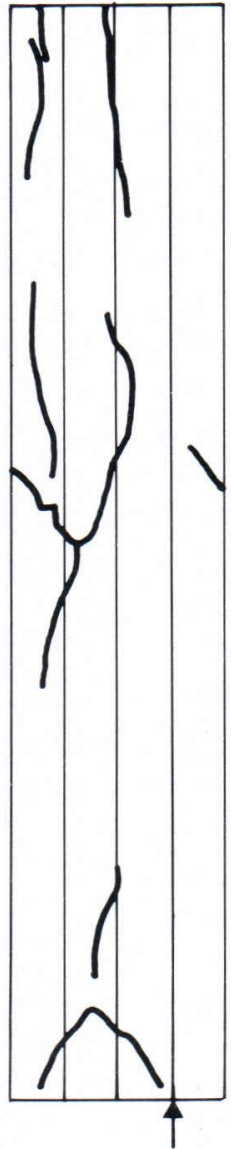

$95.9 \mathrm{~m}$

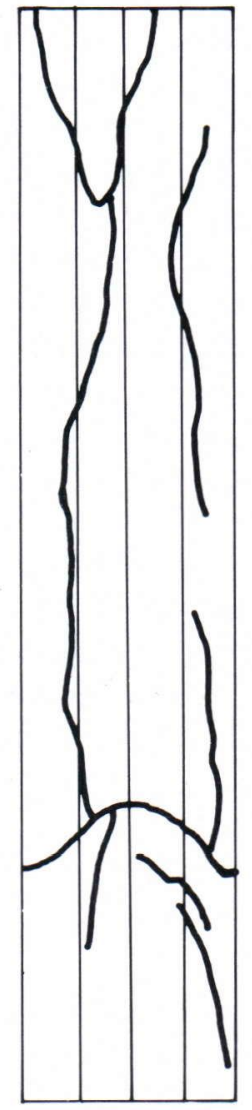

$162.8 \mathrm{~m}$

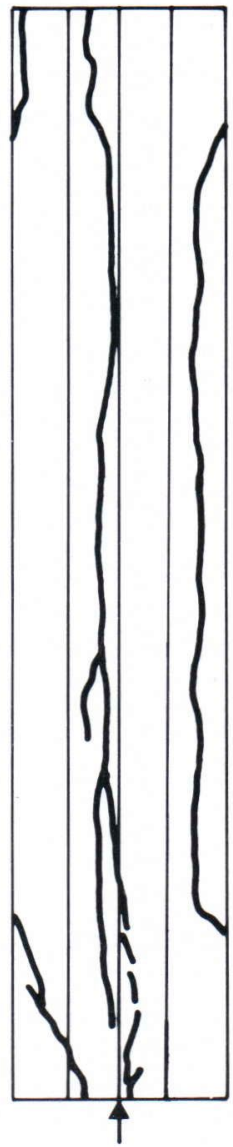

$163.3 \mathrm{~m}$

Fig. 13. Fracture impressions in the three boreholes at Stidsvig, the arrow indicates down direction in the inclined borehole DBH 82-03.

Table 5. Average state of stress from overcoring at $102 \mathrm{~m}$ depth in borehole DBH 82-01, Stidsvig, Sweden.

\begin{tabular}{|c|c|c|c|c|c|c|}
\hline \multirow[t]{2}{*}{ Stress } & \multicolumn{3}{|c|}{$\begin{array}{c}\text { Evaluation } \\
\text { excluding water pressure }\end{array}$} & \multicolumn{3}{|c|}{$\begin{array}{l}\text { Evaluation } \\
\text { including water pressure }\end{array}$} \\
\hline & $\begin{array}{l}\text { Magnitude } \\
\text { [MPa] }\end{array}$ & $\begin{array}{r}\text { Bearing } \\
\text { [degree] }\end{array}$ & $\begin{array}{c}\text { Dip } \\
\text { [degree] }\end{array}$ & $\begin{array}{l}\text { Magnitude } \\
{[\mathrm{MPa}]}\end{array}$ & $\begin{array}{l}\text { Bearing } \\
\text { [degree] }\end{array}$ & $\begin{array}{c}\text { Dip } \\
\text { [degree] }\end{array}$ \\
\hline$\sigma_{1}$ & 9.2 & 189.3 & 80 & 9.4 & 189.7 & 79.1 \\
\hline$\sigma_{2}$ & 1.6 & 35.6 & 9.1 & 2.4 & 35.8 & 9.8 \\
\hline$\sigma_{3}$ & -0.6 & 304.9 & 4.4 & 0.2 & 305 & 4.7 \\
\hline$\sigma_{\mathrm{H}}$ & 1.8 & 32.7 & - & 2.6 & 32.7 & - \\
\hline$\sigma_{\mathrm{h}}$ & -0.6 & 122.7 & - & 0.2 & 122.7 & - \\
\hline$\sigma_{\mathrm{v}}$ & 8.9 & - & 90 & 9.2 & - & 90 \\
\hline
\end{tabular}


explains the deviation in orientation of the major principal horizontal stress.

6) Rock stress measurements with the overcoring technique were conducted at Forsmark and Stidsvig before hydraulic fracturing. In the $500 \mathrm{~m}$ deep borehole at Forsmark, the results of both techniques indicate that the maximum stress is horizontal. However, the magnitudes of the stresses obtained from hydraulic fracturing are much lower. The fracture orientation device, for determination of the direction of the maximum principal stress was imperfect, and the agreement in direction of stresses cannot be judged. The poor rock quality at Stidsvig excluded the possibility of making good and reliable measurements with the overcoring technique. Except for some agreement in the direction of the principal stress, the magnitude of stresses obtained from the two methods do not agree.
Acknowledgements. This paper was prepared with the support of the Swedish Natural Science Research Council under grant number G-GU 3447-116, the National Swedish Board for Technical Development under grant number 83-3356, Sydkraft Research Foundation, grant number B 8305-06 and finally a support from Sydvatten Company and the Faculty of Engineering and Technology of the Luleå University of Technology. The authors are most grateful for the financial support from these sources, which made it possible to develop the new hydraulic fracturing measurement system. Testing at Forsmark was possible due to the kind allowance of the Swedish State Power Board to use the borehole DBT-1. The assistance from the local authority at Forsmark Nuclear Power Station is gratefully acknowledged. Research technician Arne Torikka was responsible for the development and manufacturing of the equipment, and research technician Kjell Bergström for the electronics and recording system. They also participated in the field tests at Forsmark and Stidsvig. We are most thankful to them for their good engineering and strong patience in the field. Marianne Johansson made the drawings, Dr. Peter Digby corrected the English, Bjarni Bjarnasson made valuable comments from proof-reacting and Sonja Selberg did the typing of the manuscript. We like to express our thanks for their invaluable assistance.

\section{References}

Aamodt, L. \& Kuriyagawa, M., 1983. Measurement of instantaneous shut-in pressure in crystalline rock. Proc. Workshop on Hydraulic Fracturing Stress Measurements. December 2-5, 1981. US National Committee for Rock Mechanics, Washington, DC, 139-142.

Aamodt, R. L. \& Potter, R. M., 1978. Anomalous Fracture - Extension Pressures in Granitic Rock, 19th US Symposium on Rock Mechanics, 10-13.

Bertrand, L. \& Durand, E., 1983. Mesures de constraintes in situ: comparaison de differentes methodes. In Proceedings, Soil and rock investigations by in situ testing, Paris May 18-20, 1983.

Carlsson, A., 1979. Characteristic features of a superficial rock mass in southern Central Sweden. Horizontal and subhorizontal fractures and filling materials: Striae, Uppsala, 79 p.

Cinco-Ley, H., 1982. Evaluation of Hydraulic Fracturing by Transient Pressure Analysis Methods, Paper SPE 10043 presented at the International Petroleum Exhibition and Technical Symposium of SPE, Beijing, China.

- \& Samaniego, F. V., 1981. Transient Pressure Analysis: Finite Conductivity Fracture Case versus Damaged Fracture Case, Paper SPE 10179 presented at SPE-AIME 56th Annual Fall Technical Conference and Exhibition, San Antonio.

Danesly, A. A., 1973. A study of Inclined Hydraulic Fractures. Soc. Petrol. Engr. J. 13, 61-68.

Doe, T. W.; Ingevald, K.; Strindell, L.; Haimson, B. \& Carlsson, H., 1981. Hydraulic Fracturing and Overcoring Stress Measurements in a Deep Borehole at the Stripa Test Mine, Sweden. Proc. 22nd US Symposium on Rock Mechanics, Massachusetts Institute of Technology, 373-378.

-; Hustrulid, W. A.; Leijon, B.; Ingevald, K. \& Strindell, L., 1983 a. Determination of the state of stress at the Stripa Mine, Sweden. Soc. Petrol. Engr. J. 13, 119129.

-; Ingevald, K.; Strindell, L.; Leijon, B.; Hustrulid, W. A.; Majer, E. \& Carlsson, H., 1983 b. In-situ stress measurements at the Stripa Mine, Sweden. SwedishAmerican Cooperative Program on Radioactive Waste Storage in Mined Caverns in Crystalline Rock, LBL15009 and SAC 44, 251 p.

Enever, J. R. \& Wooltorton, B. A., 1983. Experience with hydraulic fracturing as a means of estimating in-situ stress in Australian coal basin sediments. Soc. Petrol. Engr. J. $13,28-43$.

Gronseth, J. M. \& Kry, P. R., 1983. Instantaneous shut-in pressure and its relationship to the minimum in-situ stress. Proc. Workshop on Hydraulic Fracturing Stress Measurements. December 2-5, 1981. US National Committee for Rock Mechanics, Washington, DC, 55-60.

Haimson, B. C., 1978. The hydrofracturing stress measuring 
method and recent field results. Int. J. Rock Mech. Min. Sci. \& Geomech. Abstr. 15, 167-178.

-, 1983. A comparative study of deep hydrofracturing and overcoring stress measurements at six locations with particular interest to the Nevada Test Site. Proc. Workshop on Hydraulic Fracturing Stress Measurements. December 2-5, 1981. US National Committee for Rock Mechanics, Washington, DC, 107-118.

— \& Avasthi, J. M., 1974. Stress Measurements in Anisotrophic Rock by Hydraulic Fracturing, in Application of Rock Mechanics. Proc. 15th US Symposium on Rock Mechanics, ASCE, 135-156.

— \& Fairhurst, C., 1970. In-situ Stress Determination at Great Depths by Means of Hydraulic Fracturing, in Rock Mechanics Theory and Practice. Proc. 11th Symposium on Rock Mechanics, AIME, 559-584.

Hickman, S.; Healy, J.; Zoback, M. \& Svitek, J., 1981. Recent in-situ stress measurements at depth in the Western Mojave Desert. EOS, Trans AGU 62, 1048 p.

Hiltscher, R.; Martna, J. \& Strindell, L., 1979. The measurement of triaxial rock stresses in deep boreholes and the use of rock stress measurements in the design and construction of rock openings. Proc. 4th Congress International Society for Rock Mechanics, Montreaux, September 2-8, 1979, Vol. 2, 227-234.

Hubbert, M. K. \& Willis, D. G., 1957. Mechanics of hydraulic fracturing. J. Petrol. Tech. 9, 153-168.

Kehle, R. O., 1964. The determination of tectonic stresses through analysis of hydraulic well fracturing. J. Geophys. Res. Vol. 69, No. 2, 259-273.

Leeman, E. R. \& Hayes, D. T., 1966. A technique for determining the complete state of stress in rock using a single borehole. Proceeding 1st Int. Rock Mechanics Congress. Lisboa, Vol. 2, pp. 17-24.

Leijon, B., 1984. Personal communications.

-; Carlsson, H. \& Myrvang, A., 1980. The Näsliden Project - Stress measurements in Näsliden mine. Proc. Application of Rock Mechanics to Cut and Fill Mining, Luleå, June 1-3, 1980, 162-168.

Lundegårdh, P. H., 1953. Petrology of the Mölndal-StyrsöValla region in the vicinity of Gothenburg. Swedish Geological Survey, Series C 531.

Lundqvist, T., 1979. The Precambrian of Sweden. Swedish Geological Survery, Series C 768.

Martna, J.; Hiltscher, R. \& Ingevald, K., 1983. Geology and rock stresses in deep boreholes at Forsmark in Sweden. Proc. 5th Congress International Society for Rock Mechanics, Melbourne, 1983, Vol. 2, F111-F116.

McLennan, J. D., 1980. Hydraulic Fracturing - A Fracture Mechanics Approach. Ph. D. Thesis, University of Toronto.

- \& Roegiers, J-C., 1983. Do instantaneous shut-in pressures accurately represent the minimum principal stress.
Proc. Workshop on Hydraulic Fracturing Stress Measurements. December 2-5, 1981. US National Committee for Rock Mechanics, Washington, DC, 68-78.

Pine, R. J.; Ledingham, P. \& Merrifield, C. M., 1983. Insitu measurement in the Garnmenellis Granite - II. Hydrofracture tests at Rosemanowes Quarry to depth of 2000 m. Int. J. Rock Mech. Min. Sci. \& Geomech. Abstr. 20, 63-72.

Richardson, R. M., 1983. Hydraulic fracture in arbitrarily oriented boreholes; An analytical solution. Proc. Workshop on Hydraulic Fracturing Stress Measurements. December 2-5, 1981. US National Committee for Rock Mechanics, Washington, DC, 167-175.

Rummel, F.; Baumgartner, J. \& Alheid, H. J., 1983. Hydraulic fracturing stress measurements along the eastern boundary of the SW-German Block. Soc. Petrol. Engr. J. 13, 3-17.

Smith, C.; Wollendorf, W. \& Warren, W. E., 1981. In-situ stresses from hydraulic fracture measurements in $G$ tunnel, Nevade Test Site. Technical Report Sand 80-1138. Sandia National Laboratories, Albuquerque, 72 p.

Stanfors, R.; Larsson, I. \& Lindström, M., 1967. Sydvatten - Geologisk undersökning för bergtunnel. Huvudrapport. Sydkraft, Malmö.

Stephansson, O., 1975. Polydiapirism of granitic rocks in the Svecofennian of Central Sweden. Precambrian Research, 2, 189-214.

—, 1983 a. Rock stress measurement by sleeve fracturing. Proc. 5th Congress International Society for Rock Mechanics, Melbourne, 1983, Vol. 2, F129-F137.

,- 1983 b. State of the art and future plans about hydraulic fracturing stress measurements in Sweden. Proc. Workshop on Hydraulic Fracturing Stress Measurements. December 2-5, 1981. US National Committee for Rock Mechanics, Washington, DC, 260-267.

- \& Ericsson, B., 1975. Pre-Holocent joint fillings at Forsmark, Uppland, Sweden. Geologiska Föreningens i Stockholms Förhandlingar, 97, 91-95.

Sun, R. J. \& Mogan, C. E., 1974. Hydraulic fracturing at West Valley New York - A study of beddingplane fractures induced in shale for waste disposal. USGS Open File Report, 74-365.

Swedish State Power Board, 1982. Characterization of deepseated rock masses by means of borehole investigations. In-situ rock stress measurements, hydraulic testing and corelogging. Final Report, main area 5, No. 1, 155 p.

Warren, W., 1981. Packer induced stresses during hydraulic well fracturing. J. Energy Res. Techn., Transactions of the AIME, 103, 336-343.

Zoback, M. D. \& Pollard, D. D., 1978. Hydraulic fracture propagation and the interpretation of pressure time records for in-situ stress determination. 19th U.S. Symposium on Rock Mechanics, pp. 14-22. 